\title{
Supplementary information for: Yields and variability of ozone reaction products from human skin
}

Glenn Morrison $^{1 *}$, Azin Eftekhari ${ }^{1}$, Francesca Majluf ${ }^{2}$, Jordan E. Krechmer ${ }^{2}$

${ }^{1}$ Department of Environmental Sciences and Engineering, Gillings School of Global Public Health, The University of North Carolina at Chapel Hill, North Carolina, USA

${ }^{2}$ Aerodyne Research Inc., Billerica, Massachusetts, USA

*Corresponding email: glenn.morrison@unc.edu

\section{ABSTRACT}

The skin of 20 human participants was exposed to $\sim 110 \mathrm{ppb} \mathrm{O}_{3}$ and volatile products of the resulting chemistry were quantified in real time. Yields (ppb product emitted/ppb ozone consumed) for 40 products were quantified. Major products of the primary reaction of ozone-squalene included 6-methyl 5-hepten-2-one (6-MHO) and geranyl acetone (GA) with average yields of 0.22 and 0.16 respectively. Other major products included decanal, methacrolein (or methyl vinyl ketone), nonanal and butanal. Yields varied widely among participants; summed yields ranged from 0.33 to 0.93 . The dynamic increase in emission rates during ozone exposure also varied among participants, possibly indicative of differences in the thickness of the skin lipid layer. Factor analysis indicates that much of the variability among participants is due to factors associated with the relative abundance of 1 ) "fresh" skin lipid constituents (such as squalene and fatty acids), 2) oxidized skin lipids, and 3) exogenous compounds. This 
last factor appears to be associated with the presence of oleic and linoleic acids and could be accounted for by uptake of cooking oils or personal care products to skin lipids.

(31 pages, 8 tables, 12 figures) 


\section{Contents}

Supplementary information for: Yields and variability of ozone reaction products from the skin of 20 participants

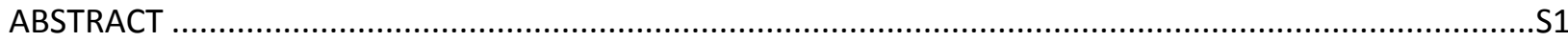

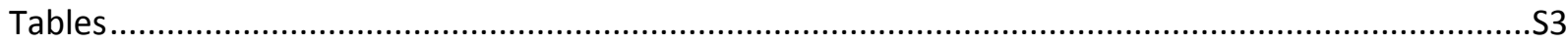

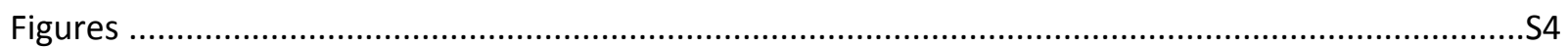

S1 Study participant recruitment and questionnaire documents .................................................5

Recruiting flyer (similar to other recruitment documents and scripts) ..........................................S5

Pre-enrollment Informational Interview and Questionnaire ....................................................S6

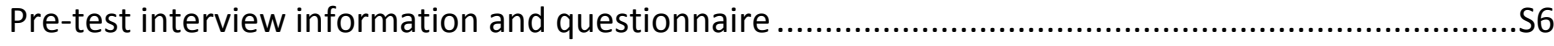

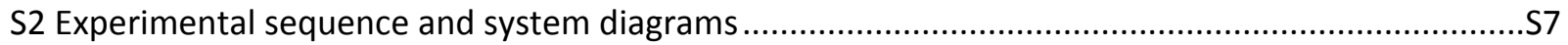

S3 PTR-TOF-MS information including calibration mixture and sniff tests ........................................S10

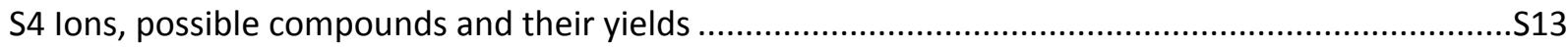

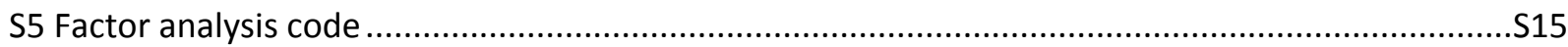

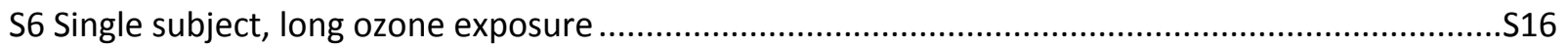

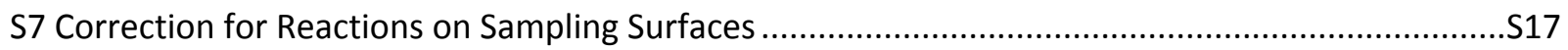

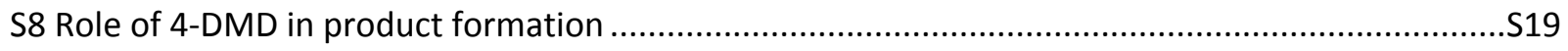

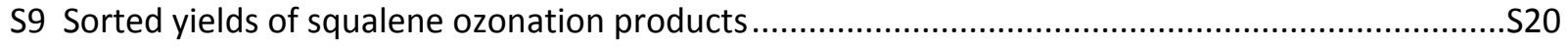

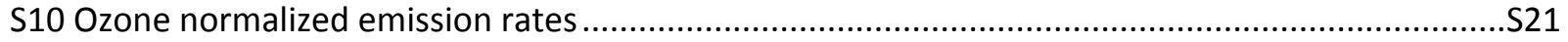

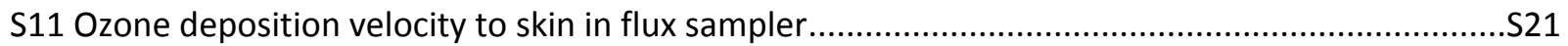

S12 Results of factor analysis are shown here for $2-5$ components. ................................................. 23

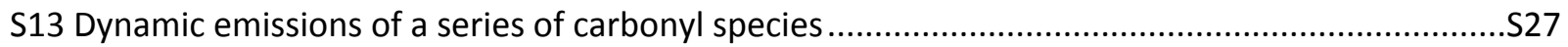

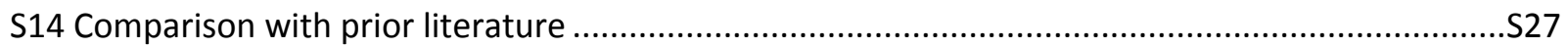

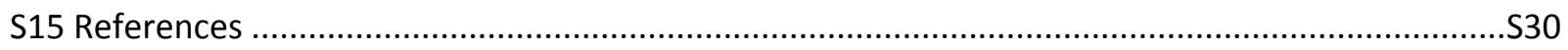




\section{Tables}

Table S 1. Ozone exposure sequence

Table S 2. Ratio of fragment-to-parent signal in counts-per-second.

Table S 3. Yields for all quantified species. Parent compounds are suggestions, but there can be many isomers. $S D=$ standard deviation; $R S D=$ relative standard deviation, $S D /$ mean; $R S D / s q r t(n)$ is also the Standard Error of the Mean (SEM) divided by the Avg value.

Table S 4. Results of 2 component solution, along with representative example compounds

Table S 5. Results of 3 component solution, along with representative example compounds

Table S 6. Results of 4 component solution, along with representative example compounds .$S 24$

Table S 7. Results of 5 component solution, along with representative example compounds. S25

Table S 8. Yields either directly reported by the authors or inferred from the information provided by the publication. 


\section{Figures}

Figure $\mathrm{S} 1$. Step 1 system diagram. Valves $\mathrm{V} 1$ and $\mathrm{V} 2$ and are shown in the off position, while $\mathrm{V} 3$ is on (ozone-free air directed to the skin). This represents step 1 of the exposure sequence (time 0:00). Black lines represent paths with flow, gray lines paths without flow.

Figure S 2. Step 2 system diagram. Valves V1 and V2 and are shown in the on position, while V3 is off (ozone bypasses skin). This represents step 2 of the exposure sequence (time 1:00). Black lines represent paths with flow, gray lines paths without flow.....

Figure S 3. Step 3 system diagram. Valves V1 and V2 and are shown in the on position, and V3 is on (ozone directed to the skin). This represents step 3 of the exposure sequence (time 3:00). Black lines represent paths with flow, gray lines paths without flow.

Figure S 4. Step 4 system diagram. Valves V1 and V2 and are shown in the off position, while V3 is on (ozone-free air directed to the skin). This represents step 4 of the exposure sequence (time 8:00) which is the same as Step 1. Black lines represent paths with flow, gray lines paths without flow.

Figure S 5: Response factor of calibration compounds versus their proton-capture rate coefficient (kcap ). Slope of 685.39 was used to obtain the response factor of other VOCs by multiplying it by their estimated kcap. Calibration compounds affected by significant uncorrected fragmentation or mass-tocharge-dependent transmission through the quadrupole ion guides were excluded from this analysis.S10

Figure S 6. Fragmentation for geranyl acetone as a function of PTR-TOF-MS source E/N, represented by the ratio of the fragment to the parent ion.

Figure $\mathrm{S}$ 7. Mixing ratio of $6 \mathrm{MHO}$ and $\mathrm{GA}$ during long-exposure experiment with a single subject. $6 \mathrm{MHO}$ results are shown in blue, left axis. GA results are shown in orange, right axis. S15

Figure S 8. The observed loss 4,9-dimethyldodeca-4,8-dienedial (4-DMD) during ozone exposure of skin suggests that this compound is present as a product of prior oxidation of squalene. S18

Figure S 9. The yield of butanal correlates with 4-DMD .$S 18$

Figure S 10. Yields of squalene ozonation products by participant. Participants are sorted here by 6-MHO yield, ascending.

Figure S 11 . Ozone normalized emission rates $\left(\mu \mathrm{g} / \mathrm{m}^{2} / \mathrm{ppb} \mathrm{O}_{3} / \mathrm{h}\right)$ for select ions. Emission rate is normalized by the outlet ozone mixing ratio $\left(\mathrm{ppb} \mathrm{O}_{3}\right)$. S20

Figure $S 12$. Normalized dynamic signals of $C_{7}$ through $C_{12}$ aliphatic carbonyl compounds, example date from one subject. S26 


\title{
S1 Study participant recruitment and questionnaire documents
}

Recruiting flyer (similar to other recruitment documents and scripts)

\section{Seeking participants for research study}

Researchers in the Environmental Sciences and Engineering Department are seeking individuals to participate in a research study of whether certain lotions protect skin from air pollution. In this study, a small area, about the size of a quarter, of skin of the forearm is coated with lotion. Air containing ozone, a pollutant, is passed over the skin area and the air is tested. We are looking for certain chemical products generated when ozone reacts with skin oil. On the day of the study, you would shower as usual, but refrain from using personal care products until after the study, which would take place later in the day. You would spend about 2 hours in the study itself and be given a $\$ 50$ gift card for your participation. The study will take place in the Michael-Hooker research labs during the week of July 8,2019 . You must be 18 years or older and have normal skin. If you are interested in participating, please contact:

\author{
Glenn Morrison, Professor \\ Environmental Sciences and Engineering \\ Gillings School of Global Public Health \\ University of North Carolina at Chapel Hill \\ (919) 966-5452 \\ glenn.morrison@unc.edu
}

Institutional Research Board

IRB \# 18-3126

IRB Contact: CB 7097

720 Martin Luther King Jr. Blvd.

Bldg \# 385, Second Floor

Chapel Hill, NC 27599-7097

$\mathrm{Ph}:$ 919-966-3113

Fax: 919-966-7879 


\section{Pre-enrollment Informational Interview and Questionnaire}

The purpose of this study is to determine whether skin lotions can reduce the amount of oxidation on skin due to exposure to air pollution. Participants will wear a small disk on their arm (like a wrist watch). Air with ozone will flow through his disk, over skin, and out to a device that measures chemicals that indicate whether ozone has reacted with skin oils. Six different skin locations will be tested, some of which will be coated with lotions. The lotions have different formulations, some intended to prevent ozone from reacting with skin.

You have indicated that you are interested in participating in this study. Before we can enroll you in the study, we need to make sure that you meet the criteria for an acceptable participant.

1) Are you 18 years of age or over? $\mathrm{Y} / \mathrm{N}$

2) Do you have a skin condition such as eczema or dermatitis? $\mathrm{Y} / \mathrm{N}$

3) Do you have skin sensitivities to lotions or other personal care products? $\mathrm{Y} / \mathrm{N}$

4) Will you be available to participate in this study between April 22 and May 10 ? $\mathrm{Y} / \mathrm{N}$

Prior to enrollment, a participant was required to complete and sign and informed consent form.

On the day of the experiment, the participant completed a brief questionnaire (see below) to verify that they have followed the preparatory procedure. Any skin reaction to the lotion or significant discomfort would halt the experiment, although this did not occur with any participants. If the participant did not comply with the pre-experimental requirements regarding showering and use of personal care products, they will be asked to return on another day or withdraw from the study; this occurred once with one subject who returned on another day. A subject that could not schedule an appointment during the testing period (a 2 week period) was withdrawn from the study; four were withdrawn for this reason.

\section{Pre-test interview information and questionnaire}

The purpose of this study is to determine whether skin lotions can reduce the amount of oxidation on skin due to exposure to air pollution. Participants will wear a small disk on their arm (like a wrist watch). Air with ozone will flow through his disk, over skin, and out to a device that measures chemicals that indicate whether ozone has reacted with skin oils. Six different skin locations will be tested, some of which will be coated with lotions. The lotions have different formulations, some intended to prevent ozone from reacting with skin.

1) What is your age?

2) What is your sex?

3) Did you shower last night but not today?

4) What kind of soap did you use to wash your skin?

5) Have you applied any personal care products after showering and if so which kinds?

6) Do you have any concerns or questions regarding the test or the consent form? 
S2 Experimental sequence and system diagrams

Table S 1. Ozone exposure sequence

\begin{tabular}{|c|c|c|l|l|}
\hline Step & $\begin{array}{c}\text { Time } \\
(\min : s e c)\end{array}$ & $(\mathrm{V} 1, \mathrm{~V} 2)$ & $(\mathrm{V} 3)$ & Notes \\
\hline 0 & $-05: 00$ & On & On & $\begin{array}{l}\text { Sampler is sealed to the back of another sampler, with ozone } \\
\text { on. This provides a value of } C_{\text {blanl }}\end{array}$ \\
\hline 1 & $00: 00$ & Off & On & $\begin{array}{l}\text { Cell is attached to forearm and clean air without ozone flows } \\
\text { through cell. }\end{array}$ \\
\hline 2 & $01: 00$ & On & Off & $\begin{array}{l}\text { Flow is directed away from the cell and ozone path is } \\
\text { opened }\end{array}$ \\
\hline 3 & $03: 00$ & On & On & Flow is directed to cell with ozone \\
\hline 4 & $08: 00$ & Off & On & Ozone is off, but flow is still directed through cell \\
\hline 5 & $10: 00$ & Off & Off & end sequence \\
\hline
\end{tabular}

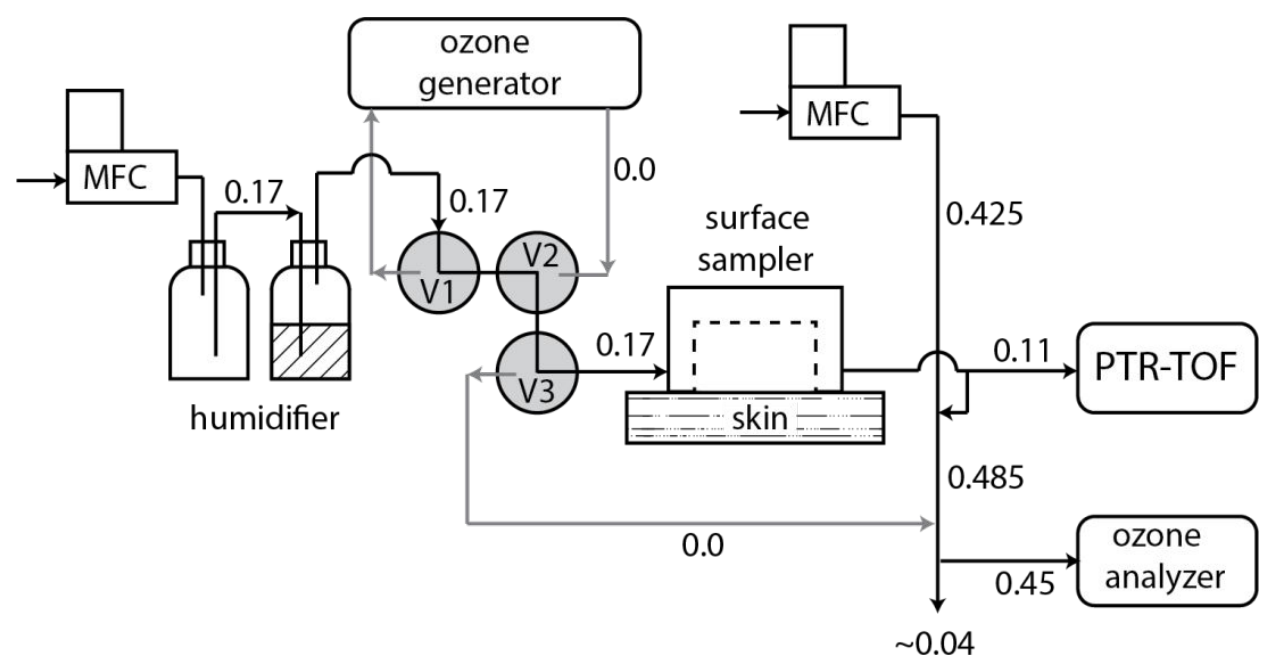

Figure S 1. Step 1 system diagram. Valves V1 and V2 and are shown in the off position, while V3 is on (ozone-free air directed to the skin). This represents step 1 of the exposure sequence (time 0:00). Black lines represent paths with flow, gray lines paths without flow. 


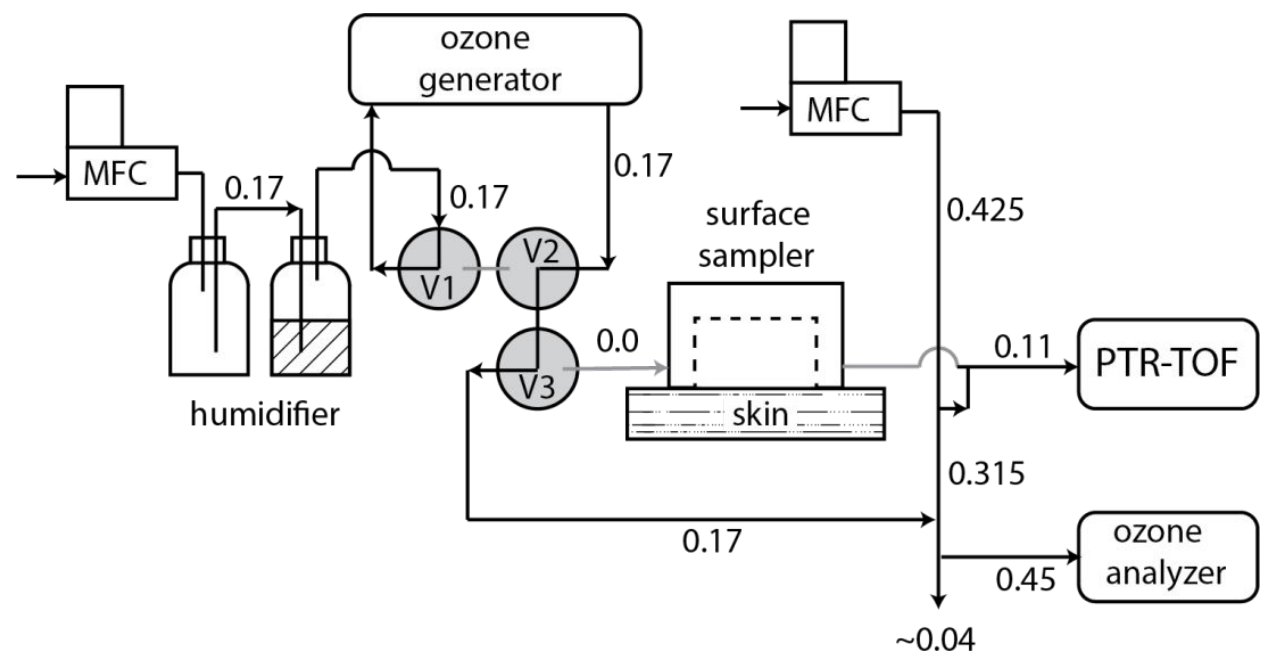

Figure S 2. Step 2 system diagram. Valves V1 and V2 and are shown in the on position, while V3 is off (ozone bypasses skin). This represents step 2 of the exposure sequence (time 1:00). Black lines represent paths with flow, gray lines paths without flow.

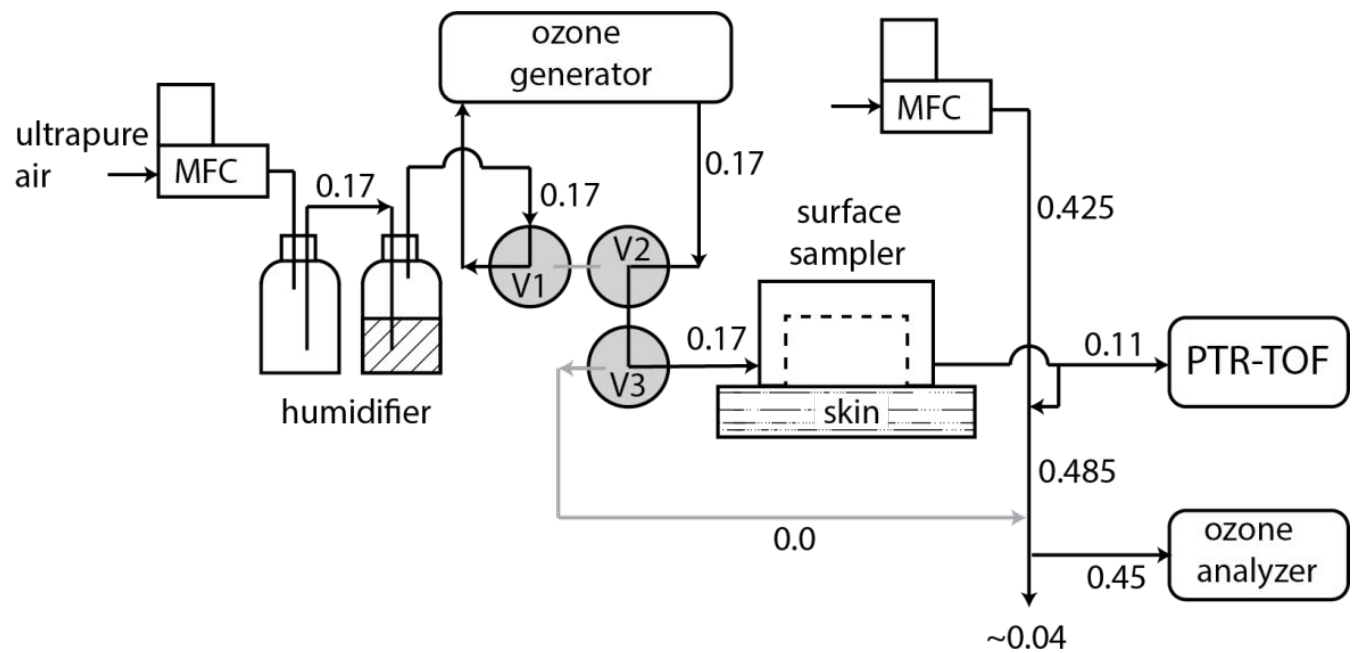

Figure S 3. Step 3 system diagram. Valves V1 and V2 and are shown in the on position, and V3 is on (ozone directed to the skin). This represents step 3 of the exposure sequence (time 3:00). Black lines represent paths with flow, gray lines paths without flow.

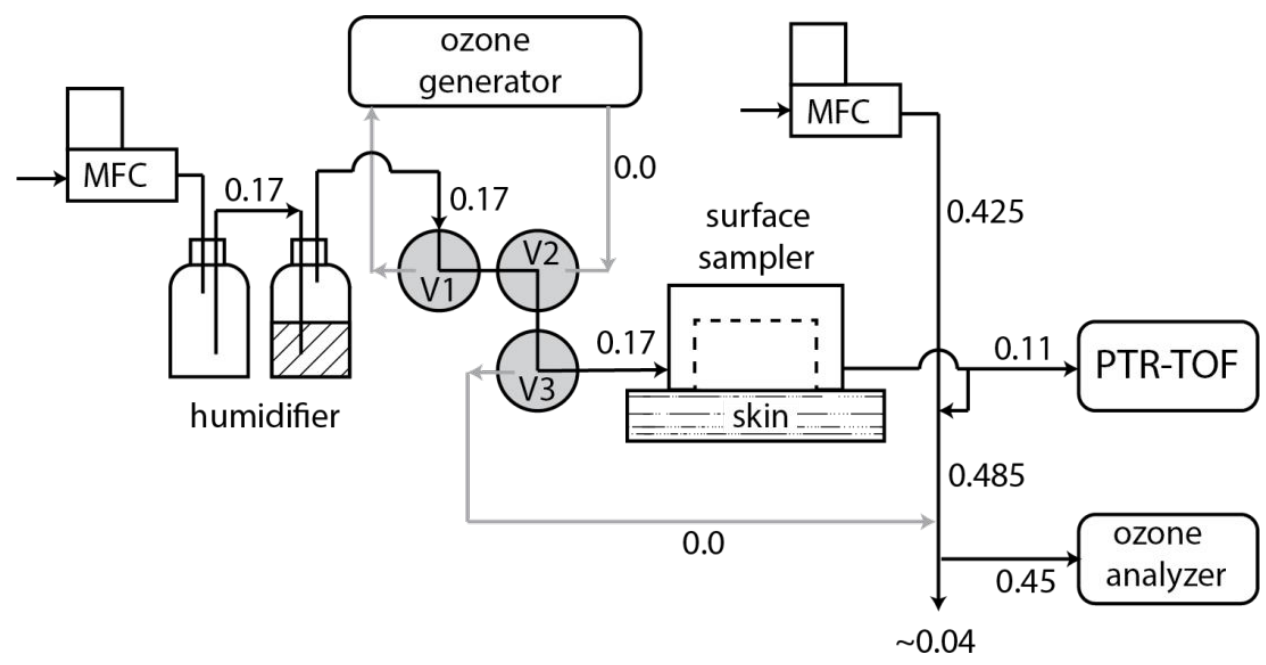


Figure S 4. Step 4 system diagram. Valves V1 and V2 and are shown in the off position, while V3 is on (ozone-free air directed to the skin). This represents step 4 of the exposure sequence (time 8:00) which is the same as Step 1. Black lines represent paths with flow, gray lines paths without flow. 


\section{S3 PTR-TOF-MS information including calibration mixture and sniff tests}

The design and function of the Vocus Proton-Transfer-Reaction Time-of-Flight Mass Spectrometer (Vocus PTR-TOF-MS) is described in more detail in Krechmer et al. ${ }^{1}$ In this work, the focusing ion molecule reactor (fIMR) was operated at a pressure of $1.5 \mathrm{mbar}$, an axial voltage difference of $475 \mathrm{~V}$, and a drift tube temperature of $100 \mathrm{C}$, corresponding to an $\mathrm{E} / \mathrm{N}$ of $\sim 160$. While this will result in more fragmentation than a more typical and lower $\mathrm{E} / \mathrm{N}$ value, we do not expect this to affect the conclusions of this work. Further, using standard injections, we measured the fragmentation pattern for critical compounds of interest including GA and 6-MHO and corrected the calibration factors accordingly. Data was recorded and saved at a $1 \mathrm{~Hz}$ time resolution and analyzed using the Tofware software (Aerodyne Research Inc. and TOFWERK) within Igor Pro (WaveMetrics).

The Vocus PTR-TOF-MS was calibrated every two hours with a 16-component VOC standard mixture containing around $1 \mathrm{ppm}$ of each compound. The 16-components consisted of common outdoor atmospheric volatile constituents of varying functional groups (e.g. acetonitrile, acetone, benzene, isoprene, methyl ethyl ketone, etc.). During each calibration period, the inlet was overflowed with the VOC mixture diluted 100x into zero air, resulting in sampling approximately $10 \mathrm{ppb}$ of each VOC standard. The zero air used for dilution and background measurements was generated by pushing room air through a hydrocarbon scrubber (Vici Metronics). The Vocus PTR-TOF-MS has no humidity dependence and thus no $\mathrm{RH}$-dependent calibrations were performed. Background measurements were performed before and after every calibration period.

The sensitivity of each sampled analyte molecule is a linear function of its proton capture rate coefficient with the hydronium ion ${ }^{2,3}$ The response factors of compounds at a $16.4 \mathrm{KHz}$ TOF extraction frequency in the standard mixture were plotted against their known $k_{\text {cap }}$ and fit to a linear regression (figure S5). Good agreement $\left(r^{2}=0.92\right)$ was obtained between the measured response factors and those using their known $k_{\text {cap }}$.

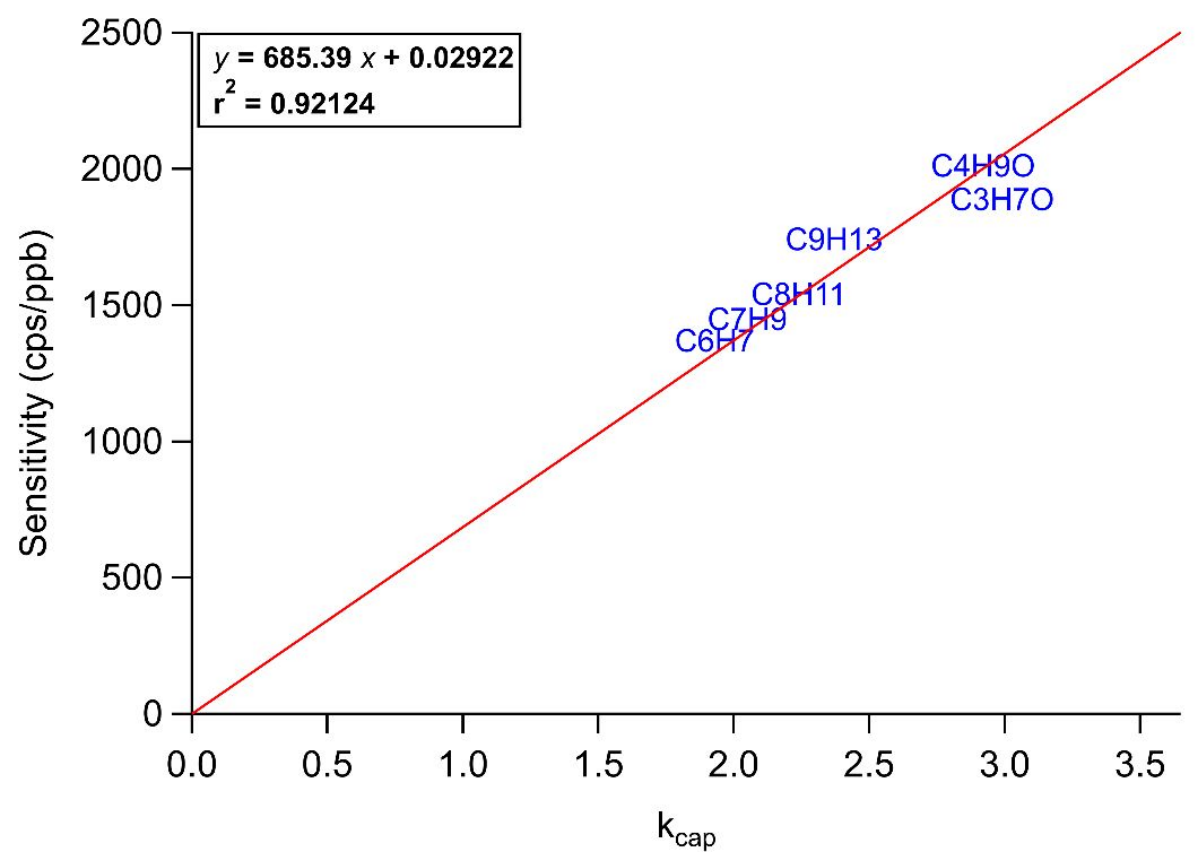


Figure S 5: Response factor of calibration compounds versus their proton-capture rate coefficient ( $k_{\text {cap }}$ ). Slope of 685.39 was used to obtain the response factor of other VOCs by multiplying it by their estimated $k_{\text {cap. }}$. Calibration compounds affected by significant uncorrected fragmentation or mass-to-charge-dependent transmission through the quadrupole ion guides were excluded from this analysis.

The $k_{\text {cap }}$ of compounds not found in the standard mixture can be estimated using the polarizability and dipole moment of the elemental formula extracted from the mass spectrum using a previously developed parameterization $^{3}$, which is then adjusted by the following equation, where $f_{V O C}$ is the estimated response factor of a given VOC in counts-per-second per ppb, $m$ is the slope on figure $\mathrm{S} 5$, and $k_{c a p, V O C}$ is the estimated $k_{\text {cap }}$ for the given VOC.

$f_{V O C}=m \times k_{c a p, V O C}$

To correct for the fragmentation of $6 \mathrm{MHO}$ and $\mathrm{GA}$, non-quantitative amounts of chemical standard were introduced to the instrument. Each standard introduction consisted of the sampling the headspace of the pure chemical in question by quickly opening and closing the bottle in front of the Vocus PTR-TOF-MS's inlet. The procedure was repeated three times and the average ratio between the parent molecule and its fragment was calculated. Table S2 below lists the resulting fragment-to-parent ratios for both 6-MHO and GA for the PTR-TOF-MS source settings used in this experiment.

Table S 2. Ratio of fragment-to-parent signal in counts-per-second.

\begin{tabular}{c|cc|c|}
\hline Compound & Parent lon & Fragment lon & Fragment-to-parent signal ratio \\
\hline 6-MHO & $\mathrm{C}_{8} \mathrm{H}_{14} \mathrm{OH}^{+}$ & $\mathrm{C}_{8} \mathrm{H}_{12} \mathrm{H}^{+}$ & 4.21 \\
\hline $\mathrm{GA}$ & $\mathrm{C}_{13} \mathrm{H}_{22} \mathrm{OH}^{+}$ & $\mathrm{C}_{13} \mathrm{H}_{20} \mathrm{H}^{+}$ & 3.55 \\
\hline
\end{tabular}

Due to the unusually high E/N used in this study, fragmentation for 6-MHO and GA were higher than observed in other studies (e.g. Wisthaler and Weschler, 2010 4 ). The fragmentation ratio is dependent on the electric field to number density ratio, or $E / N$, typically represented in units of Townsend (Td). Figure S.6. shows a plot of the relative amount of fragmentation for geranyl acetone as a function of PTR-TOFMS E/N. To take these data, the PTR-TOF-MS axial voltage and temperature were held constant, and the source pressure was varied to keep transmission constant while changing $\mathrm{E} / \mathrm{N}$. 


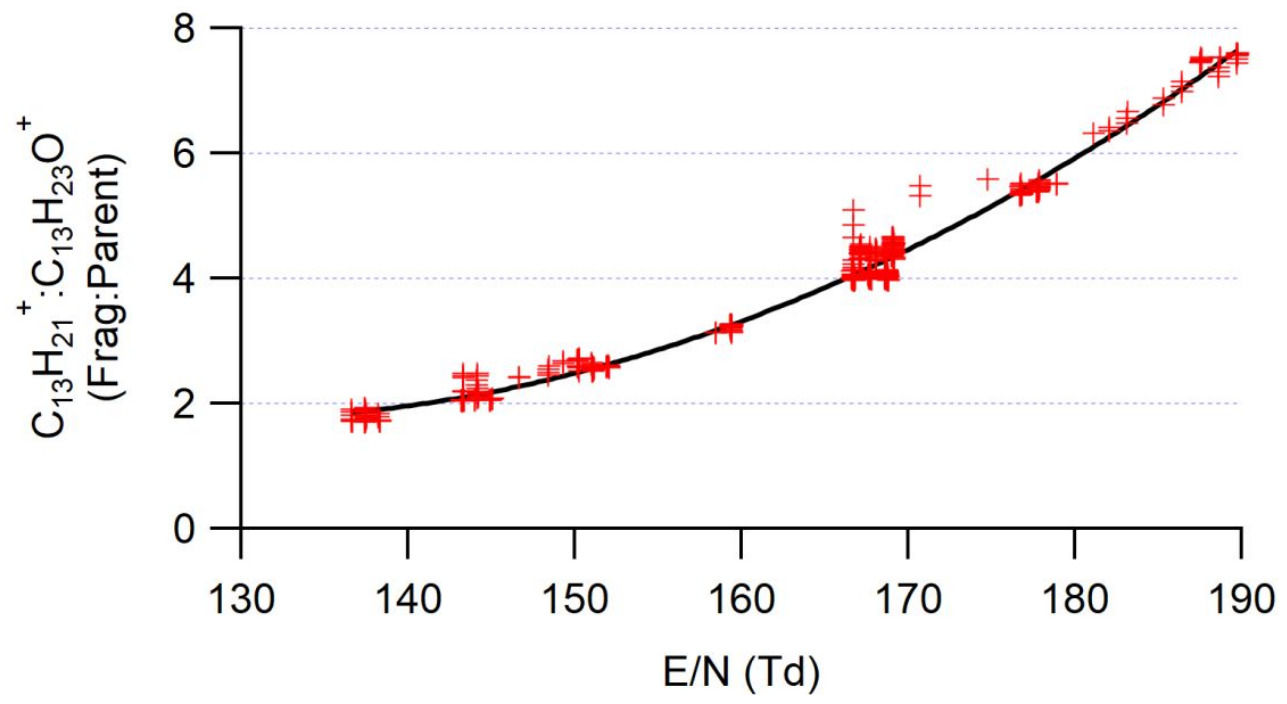

Figure S 6. Fragmentation for geranyl acetone as a function of PTR-TOF-MS source E/N, represented by the ratio of the fragment to the parent ion. 
S4 lons, possible compounds and their yields

Table S 3. Yields for all quantified species. Parent compounds are suggestions, but there can be many isomers. SD= standard deviation; RSD= relative standard deviation, $S D /$ mean; RSD/sqrt(n) is also the Standard Error of the Mean (SEM) divided by the Avg value.

\begin{tabular}{|c|c|c|c|c|c|c|c|c|c|c|}
\hline Ion & Parent & Avg & SD & Min & Max & RSD & $\begin{array}{l}\text { RSD/ } \\
\text { sqrt(n) }\end{array}$ & Median & 0.25 & 0.75 \\
\hline $\mathrm{C} 4 \mathrm{H} 7 \mathrm{O}+$ & methacrolein & 0.031 & 0.007 & 0.018 & 0.049 & 0.237 & 0.053 & 0.031 & 0.027 & 0.036 \\
\hline $\mathrm{C} 3 \mathrm{H} 5 \mathrm{O} 2+$ & acrylic acid & 0.006 & 0.003 & 0.001 & 0.011 & 0.453 & 0.101 & 0.006 & 0.004 & 0.008 \\
\hline $\mathrm{C} 4 \mathrm{H} 9 \mathrm{O}+$ & butanal, 2-butanone & 0.006 & 0.002 & 0.001 & 0.009 & 0.313 & 0.070 & 0.006 & 0.005 & 0.007 \\
\hline $\mathrm{C} 5 \mathrm{H} 7 \mathrm{O}+$ & pentadienal & 0.032 & 0.006 & 0.022 & 0.042 & 0.180 & 0.040 & 0.032 & 0.029 & 0.036 \\
\hline $\mathrm{C} 5 \mathrm{H} 9 \mathrm{O}+$ & pentenal & 0.006 & 0.003 & -0.005 & 0.009 & 0.546 & 0.122 & 0.007 & 0.005 & 0.008 \\
\hline $\mathrm{C} 4 \mathrm{H} 7 \mathrm{O} 2+$ & butanedial & 0.024 & 0.006 & 0.013 & 0.035 & 0.257 & 0.057 & 0.024 & 0.019 & 0.030 \\
\hline $\mathrm{C} 5 \mathrm{H} 110+$ & Pentanal, meth & 0.002 & 0.001 & 0.000 & 0.004 & 0.468 & 0.105 & 0.002 & 0.001 & 0.002 \\
\hline $\mathrm{C} 4 \mathrm{H} 9 \mathrm{O} 2+$ & butyric & 0.002 & 0.001 & 0.000 & 0.004 & 0.397 & 0.089 & 0.003 & 0.002 & 0.003 \\
\hline $\mathrm{C} 5 \mathrm{H} 7 \mathrm{O} 2+$ & 4-oxo-pentenal & 0.006 & 0.001 & 0.004 & 0.009 & 0.203 & 0.045 & 0.006 & 0.005 & 0.007 \\
\hline $\mathrm{C} 4 \mathrm{H} 5 \mathrm{O} 3+$ & 4-oxo-2-butenoic acid & 0.004 & 0.002 & 0.001 & 0.008 & 0.463 & 0.104 & 0.004 & 0.003 & 0.005 \\
\hline $\mathrm{C} 5 \mathrm{H} 9 \mathrm{O} 2+$ & 4OPA & 0.007 & 0.019 & -0.038 & 0.047 & 2.565 & 0.574 & 0.013 & 0.001 & 0.016 \\
\hline $\mathrm{C} 6 \mathrm{H} 13 \mathrm{O}+$ & hexanal & 0.001 & 0.000 & 0.000 & 0.002 & 0.748 & 0.167 & 0.001 & 0.000 & 0.001 \\
\hline C5H11O2+ & id, hydroxy-pentenone & 0.001 & 0.001 & -0.001 & 0.002 & 0.596 & 0.133 & 0.001 & 0.001 & 0.002 \\
\hline $\mathrm{C} 7 \mathrm{H}$ & C7- & 0.009 & 0.002 & 0.004 & 0.015 & 53 & 0.059 & 0.009 & 0.008 & 0.011 \\
\hline $\mathrm{C7H} 130+$ & heptenal & 0.002 & 0.001 & 0.001 & 0.003 & 0.271 & 0.061 & 0.002 & 0.002 & 0.003 \\
\hline C6H11O2+ & hexenoic acid, hydroxy-hexenone & 0.002 & 0.001 & 0.000 & 0.004 & 0.491 & 0.110 & 0.003 & 0.002 & 0.003 \\
\hline $\mathrm{C} 7 \mathrm{H} 15 \mathrm{O}+$ & heptanal & 0.000 & 0.000 & 0.000 & 0.001 & 0.478 & 0.107 & 0.001 & 0.000 & 0.001 \\
\hline $\mathrm{C} 8 \mathrm{H} 13 \mathrm{O}+$ & C8-MUC & 0.004 & 0.001 & 0.003 & 0.007 & 0.238 & 0.053 & 0.004 & 0.004 & 0.005 \\
\hline $\mathrm{C} 8 \mathrm{H} 15 \mathrm{O}+$ & $6 \mathrm{MHO}$ & 0.219 & 0.081 & 0.058 & 0.431 & 0.370 & 0.083 & 0.212 & 0.184 & 0.279 \\
\hline $\mathrm{C} 7 \mathrm{H} 13 \mathrm{O} 2+$ & heptenoic acid & 0.002 & 0.000 & 0.001 & 0.002 & 0.207 & 0.046 & 0.002 & 0.001 & 0.002 \\
\hline $\mathrm{C} 8 \mathrm{H} 17 \mathrm{O}+$ & octanal & 0.002 & 0.001 & 0.000 & 0.003 & 0.405 & 0.091 & 0.001 & 0.001 & 0.002 \\
\hline $\mathrm{C} 8 \mathrm{H} 8 \mathrm{NO}+$ & unknown & -0.003 & 0.001 & -0.006 & 0.000 & -0.402 & -0.090 & -0.002 & -0.003 & -0.002 \\
\hline
\end{tabular}




\begin{tabular}{|c|c|}
\hline Ion & Parent \\
\hline $\mathrm{C} 9 \mathrm{H} 13 \mathrm{O}+$ & C9-MUC \\
\hline $\mathrm{C} 8 \mathrm{H} 1102+$ & unknown \\
\hline $\mathrm{C} 9 \mathrm{H} 15 \mathrm{O}+$ & C9-MUC \\
\hline C7H9O3+ & unknown \\
\hline $\mathrm{C} 9 \mathrm{H} 170+$ & nonenal \\
\hline $\mathrm{C} 8 \mathrm{H} 15 \mathrm{O} 2+$ & OH-6МHO \\
\hline С9H19O+ & nonanal \\
\hline $\mathrm{C} 10 \mathrm{H} 15 \mathrm{O}+$ & C10-MUC \\
\hline $\mathrm{C9H} 15 \mathrm{O} 2+$ & 4-MOD \\
\hline $\mathrm{C} 10 \mathrm{H} 190+$ & geraniol \\
\hline $\mathrm{C} 10 \mathrm{H} 210+$ & decanal \\
\hline $\mathrm{C9H} 2102+$ & nonanediol \\
\hline $\mathrm{C} 10 \mathrm{H} 15 \mathrm{O} 2+$ & unknown \\
\hline $\mathrm{C} 10 \mathrm{H} 17 \mathrm{O} 2+$ & $4 \mathrm{MON}$ \\
\hline $\mathrm{C} 11 \mathrm{H} 230+$ & undecanal \\
\hline $\mathrm{C} 10 \mathrm{H} 23 \mathrm{O} 2+$ & decanediol \\
\hline $\mathrm{C} 13 \mathrm{H} 23 \mathrm{O}+$ & $\mathrm{GA}$ \\
\hline $\mathrm{C} 15 \mathrm{H} 230+$ & unknown \\
\hline $\begin{array}{l}\mathrm{C} 14 \mathrm{H} 2102+ \\
\text { sum }\end{array}$ & 4-DMD \\
\hline
\end{tabular}

\begin{tabular}{rlrllrrrrr} 
Avg & SD & Min & Max & \multicolumn{1}{l}{ RSD } & RSdt(n) & Median & $\mathbf{0 . 2 5}$ & $\mathbf{0 . 7 5}$ \\
0.002 & 0.001 & 0.001 & 0.004 & 0.395 & 0.088 & 0.002 & 0.001 & 0.002 \\
-0.030 & 0.012 & -0.053 & 0.001 & -0.386 & -0.086 & -0.028 & -0.034 & -0.024 \\
0.001 & 0.000 & 0.001 & 0.002 & 0.333 & 0.074 & 0.001 & 0.001 & 0.002 \\
-0.002 & 0.001 & -0.004 & 0.000 & -0.408 & -0.091 & -0.002 & -0.003 & -0.002 \\
0.004 & 0.004 & 0.001 & 0.017 & 0.883 & 0.197 & 0.003 & 0.003 & 0.005 \\
0.006 & 0.002 & 0.003 & 0.010 & 0.253 & 0.057 & 0.006 & 0.005 & 0.007 \\
0.009 & 0.006 & 0.003 & 0.027 & 0.698 & 0.156 & 0.007 & 0.006 & 0.010 \\
0.006 & 0.002 & 0.003 & 0.009 & 0.319 & 0.071 & 0.006 & 0.005 & 0.007 \\
0.001 & 0.000 & 0.001 & 0.002 & 0.388 & 0.087 & 0.001 & 0.001 & 0.001 \\
0.002 & 0.001 & 0.001 & 0.004 & 0.364 & 0.081 & 0.002 & 0.002 & 0.003 \\
0.016 & 0.005 & 0.007 & 0.025 & 0.345 & 0.077 & 0.016 & 0.012 & 0.020 \\
0.003 & 0.002 & 0.001 & 0.009 & 0.763 & 0.171 & 0.002 & 0.002 & 0.003 \\
0.001 & 0.000 & 0.001 & 0.002 & 0.259 & 0.058 & 0.001 & 0.001 & 0.001 \\
0.002 & 0.000 & 0.001 & 0.003 & 0.235 & 0.053 & 0.002 & 0.002 & 0.003 \\
0.002 & 0.001 & 0.001 & 0.005 & 0.338 & 0.076 & 0.002 & 0.002 & 0.003 \\
0.006 & 0.002 & 0.002 & 0.010 & 0.356 & 0.080 & 0.005 & 0.004 & 0.007 \\
0.163 & 0.045 & 0.094 & 0.275 & 0.276 & 0.062 & 0.158 & 0.133 & 0.190 \\
-0.002 & 0.001 & -0.004 & 0.000 & -0.515 & -0.115 & -0.002 & -0.003 & -0.001 \\
-0.006 & 0.002 & -0.010 & 0.000 & -0.406 & -0.091 & -0.005 & -0.007 & -0.005 \\
0.550 & 0.147 & 0.330 & 0.930 & 0.267 & 0.060 & 0.548 & 0.479 & 0.651
\end{tabular}




\section{S5 Factor analysis code}

Factor analysis on yields of selected ions was performed using SPSS 26. Code is shown here for 3 factor analysis:

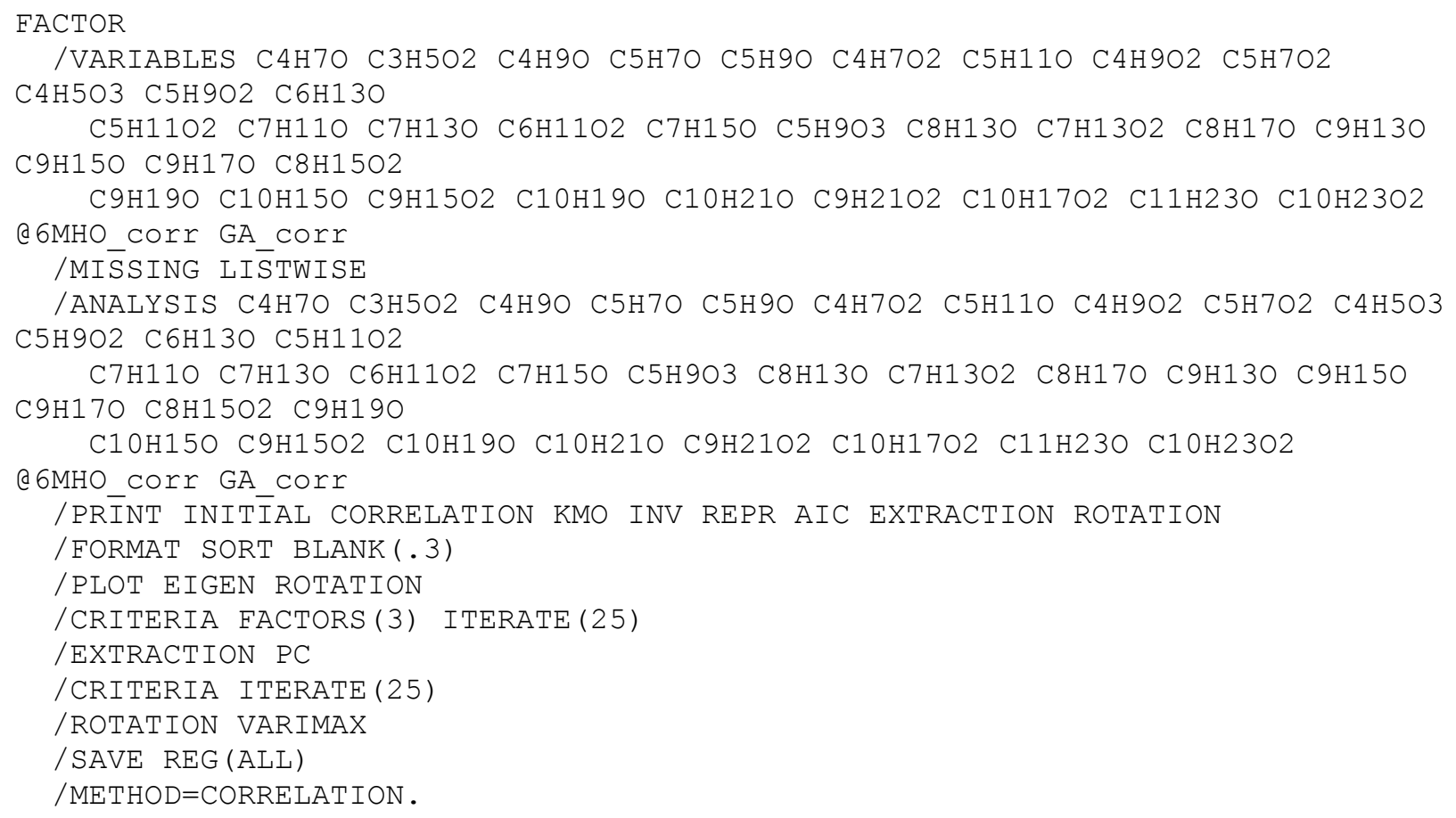


S6 Single subject, long ozone exposure

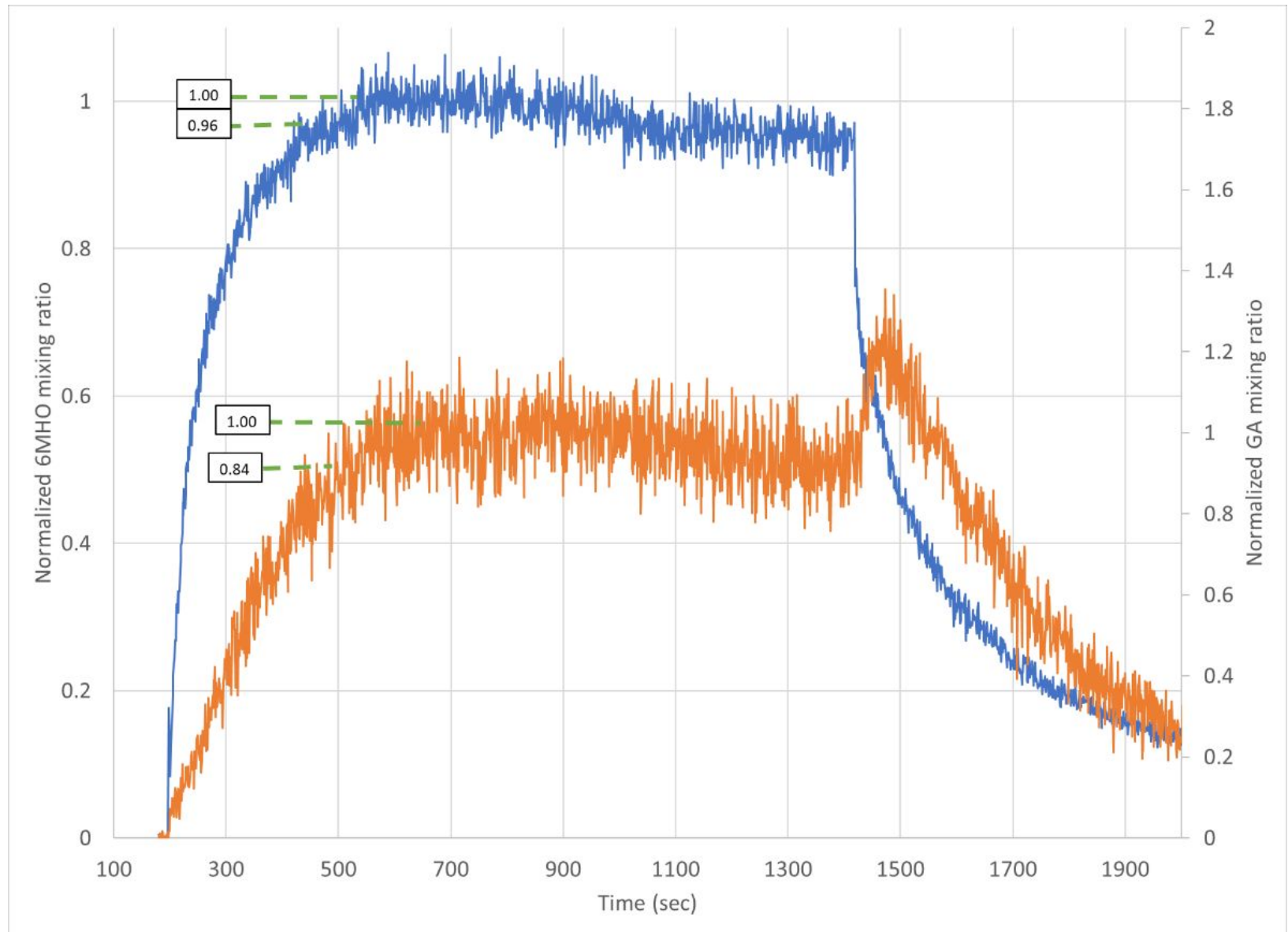

Figure S 7. Mixing ratio of $6 \mathrm{MHO}$ and GA during long-exposure experiment with a single subject. $6 \mathrm{MHO}$ results are shown in blue, left axis. GA results are shown in orange, right axis. 


\section{S7 Correction for Reactions on Sampling Surfaces}

Loss of some products, especially GA, are likely occurring due to deposition and heterogeneous ozone chemistry within the tubing, fittings and inlet of the PTR-TOF-MS. Sorption to tubing has been described in detail and models have been developed to predict the time delays associated with sorption ${ }^{5,6}$. Under steady-state conditions, we would anticipate that tubing delays would not be a factor (in the absence of other chemistry), but steady-state is not quite reached during the 5 min ozone exposure period. This can be seen more clearly with a longer exposure experiment (See Figure S7). Several phenomena are apparent:

Approach to steady-state. Neither 6-MHO nor GA signals have quite reached steady state by 300 seconds. By $\sim 400$ seconds, both have reached a steady state condition and then decrease over time, probably due to slow depletion of squalene in skin lipids. For this long-exposure experiment, 6-MHO reaches $96 \%$ of steady-state by 300 seconds. However, GA only reaches $84 \%$ of its eventual steady state.

Adsorption and possible ozonolysis of GA on system surfaces. When ozone is turned off, we observed two simultaneous features in the 6-MHO and GA signals. First, the 6-MHO signal decreases nearly instantaneously by $23 \%$ (within 2 seconds). Given desorption kinetics from skin, this rapid reduction is much faster than anticipated. Second, the GA signal slowly rises to a peak, then begins to decay. In combination, these two results indicate that GA that has adsorbed to the inner surfaces of the sampling system is reacting with ozone, generating 6-MHO and possibly other products. When ozone is turned off, this GA loss pathway on the tubing is shut down, allowing its concentration to rise as it desorbs from the tubing and skin. Simultaneously the 6-MHO concentration drops because it has ceased to be produced by the surface reaction of ozone with GA; it drops much more quickly because it is does not adsorb strongly to the tubing and there is no significant reservoir of 6-MHO desorbing into the sample flow. For the same reason, we do not anticipate significant loss of 6-MHO by heterogenous ozonolysis.

To quantitatively account for this chemistry in our reported yields, we assume that the immediate postozone (302-303 seconds) value of 6-MHO is the correct value, recognizing that this may still overrepresent the actual steady-state value. For consistency, we multiply the average value from 290-300 seconds for each experiment by 0.81 , which is the average ratio of the post-ozone value to the "during ozone" value across all subjects. Therefore, the corrected mixing ratio of 6-MHO, $C_{6-M H O}$ corrected, is

$C_{6 M H O \_ \text {corrected }}=0.81 * C_{6 M H O \_O 3}$ 
To correct the GA value, we consider simple stoichiometry associated with ozonolysis of GA (Figure 2 of the main manuscript). Ozone can react with two different double bonds on GA, only one of which will generate 6-MHO. Assuming an equal probability of reacting with either double bond, and the formation of only carbonyl species, then the loss in GA is roughly equal to twice the production rate of 6-MHO. Therefore, the corrected mixing ratio of $G A, C_{G A}$ corrected, is

$C_{G A_{-} \text {corrected }}=C_{G A_{-} O 3}+2 *(1-0.81) * C_{6 M H O \_O 3}$

Although neither 6-MHO or GA quite reach steady state, we do not correct for this since the correction would be relatively small. Yields for 6-MHO and GA reported here are based on these corrections (and those described in the methods).

It is possible that even after accounting for ozonolysis, the GA signal is lower than it should be. Based on the models described by Pagonis et al. ${ }^{5}$, a large fraction of GA is expected to be taken up by the tubing. Although GA appears to approach steady state at 400 seconds, this could reflect continuous deposition of GA to tubing surfaces. It is not yet possible to use such models to confidently back-calculate the transmission fraction. This phenomenon, however, tells us that the GA yields reported here are likely to be a lower limit, subject to improvement with an experimental system that has less sampling surface area. 
S8 Role of 4-DMD in product formation

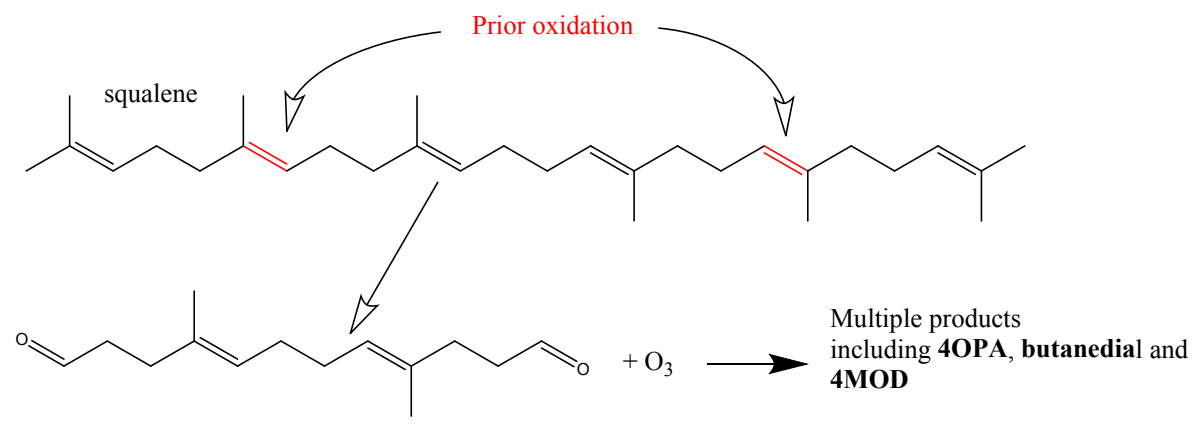

\section{$\mathrm{C}_{14} \mathrm{H}_{20} \mathrm{O}_{2} \quad$ 4,9-dimethyldodeca-4,8-dienedial}

Figure S 8. The observed loss 4,9-dimethyldodeca-4,8-dienedial (4-DMD) during ozone exposure of skin suggests that this compound is present as a product of prior oxidation of squalene.

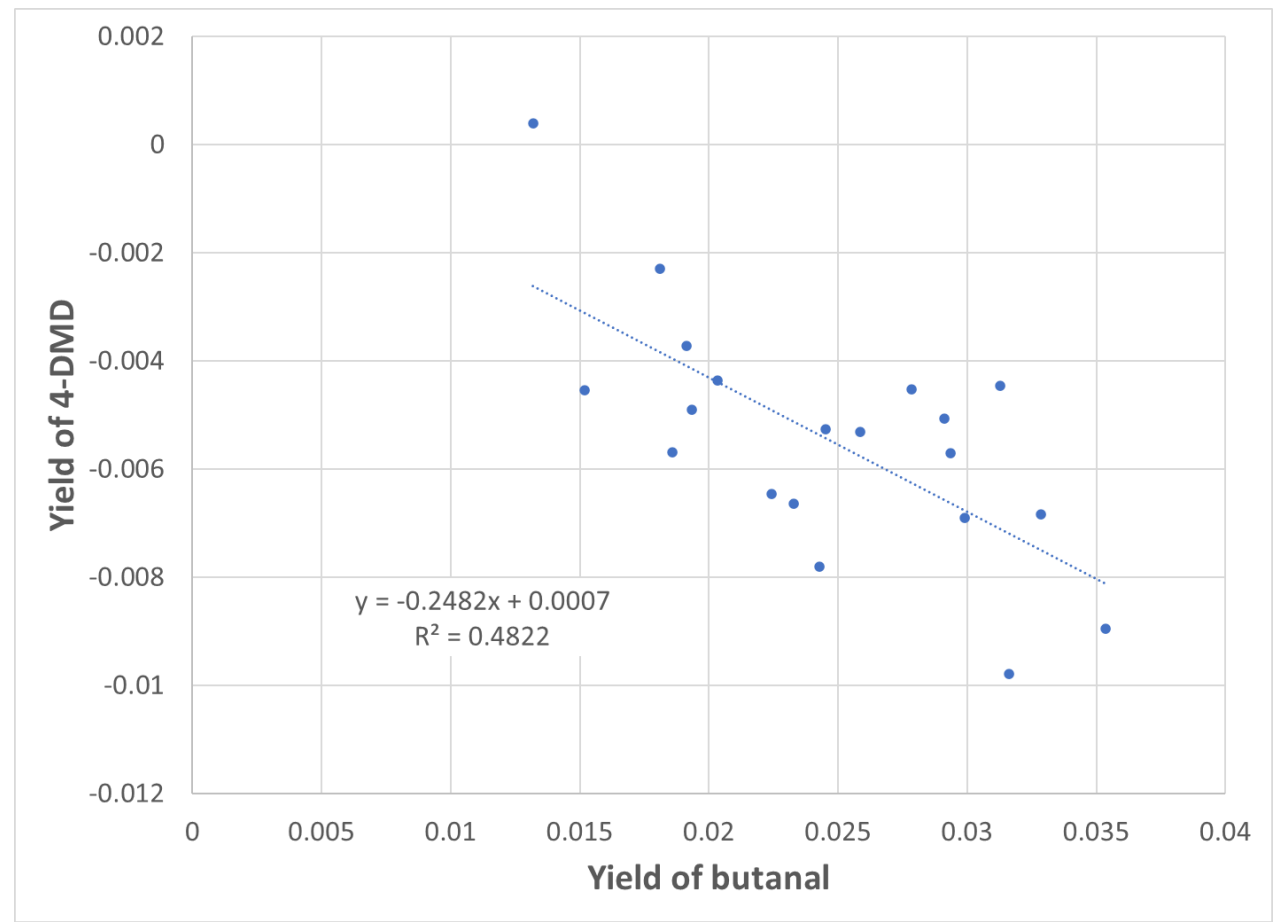

Figure S 9. The yield of butanal correlates with 4-DMD 
S9 Sorted yields of squalene ozonation products

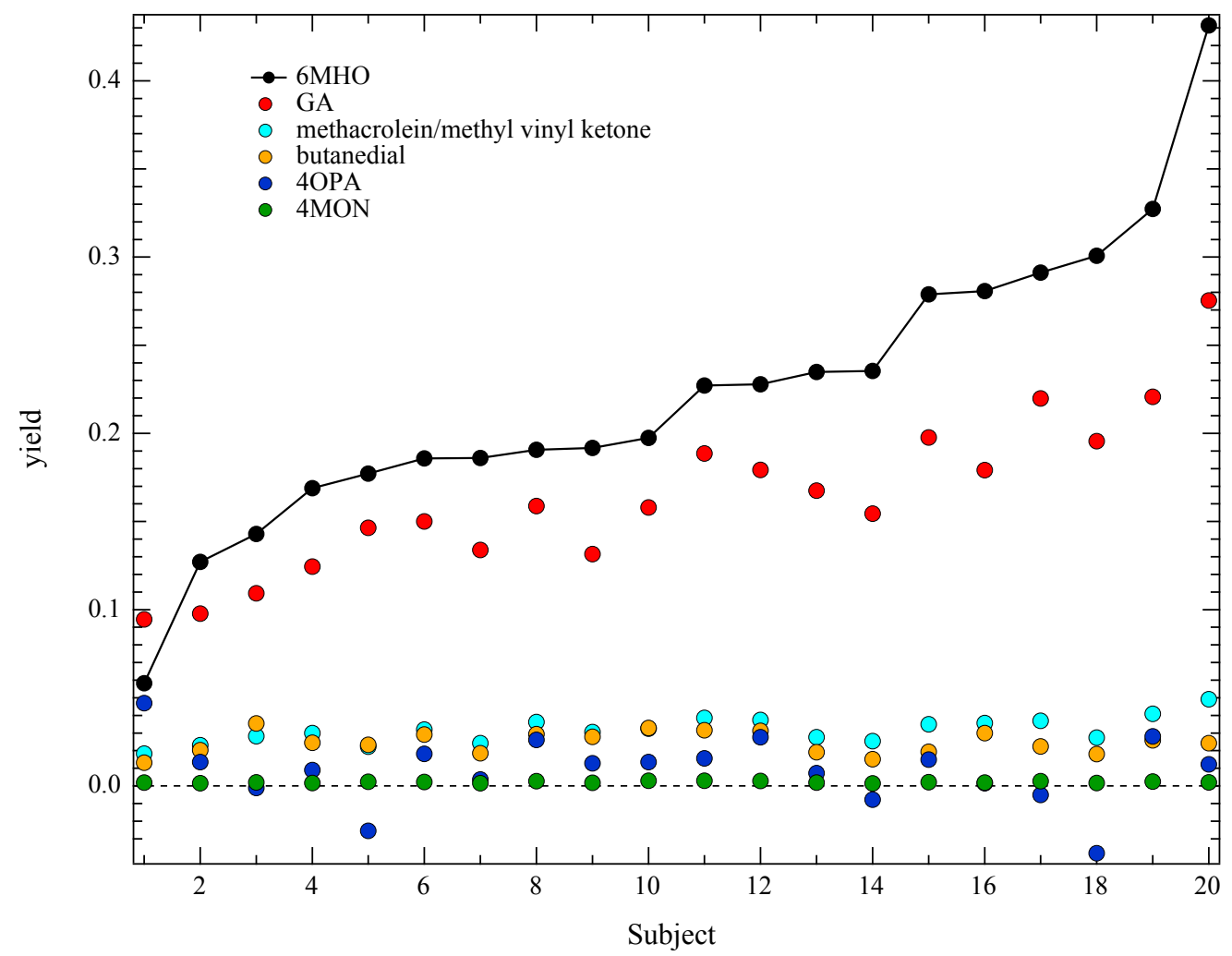

Figure S 10. Yields of squalene ozonation products by participant. Participants are sorted here by 6-MHO yield, ascending. 


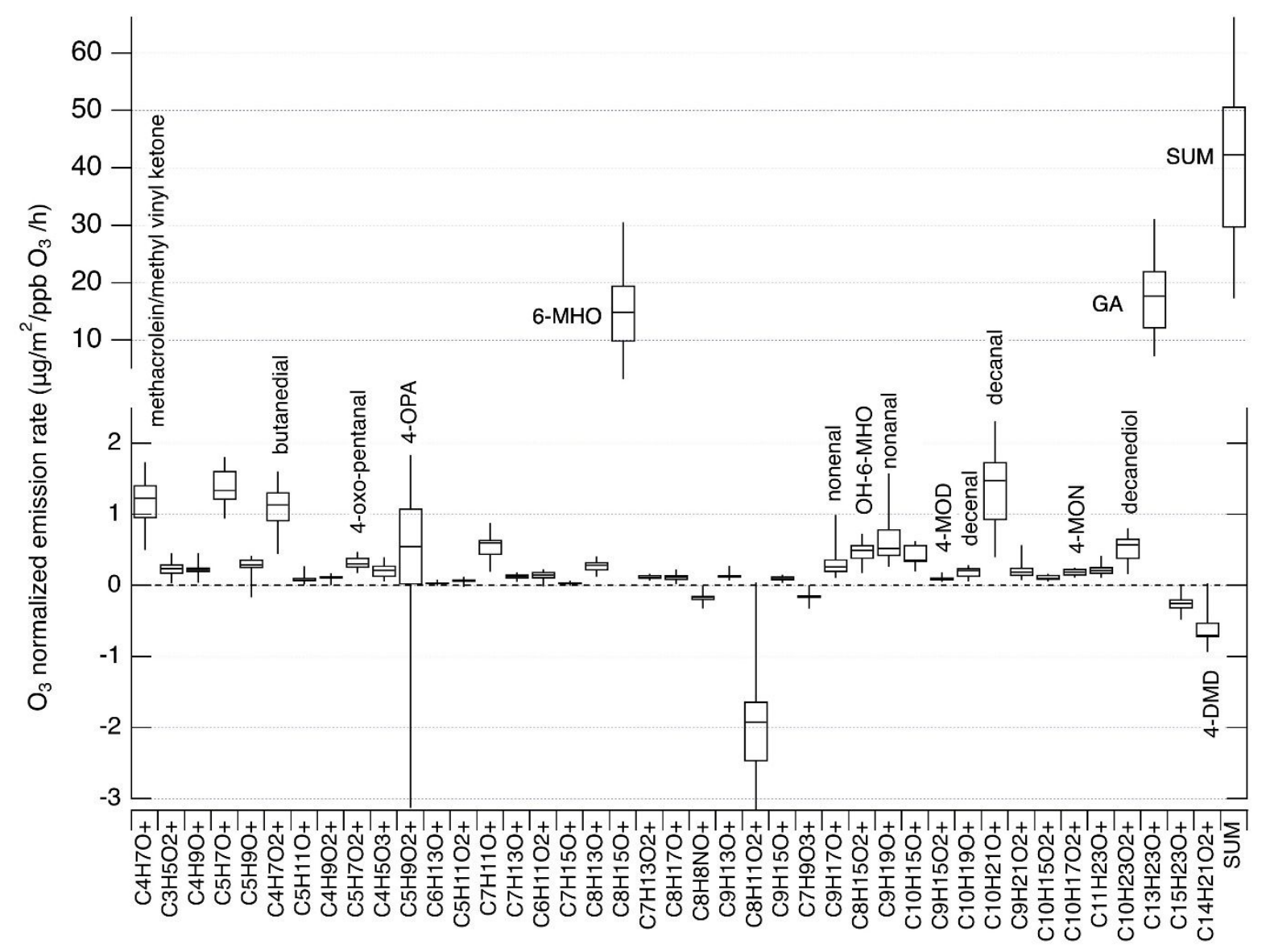

Figure $\mathrm{S} 11$. Ozone normalized emission rates $\left(\mu \mathrm{g} / \mathrm{m}^{2} / \mathrm{ppb} \mathrm{O}_{3} / \mathrm{h}\right)$ for select ions. Emission rate is normalized by the outlet ozone mixing ratio $\left(\mathrm{ppb}_{3}\right)$.

\section{S11 Ozone deposition velocity to skin in flux sampler}

The system, comprising inlet tubing to the flux cell, flux cell and outlet tubing comprises a system that has some ozone removal capability, independent of uptake at the skin. This background removal capability has to be characterized before calculating the deposition velocity at the skin surface. Background removal also influences back-calculated ozone uptake and ozone concentrations over the skin. The system can be simplified as shown here,

The system inlet concentration, $C_{03, \text { system_inlet, }}$ is the measured upstream concentration on bypass after being corrected for dilution (see Figure S2 and description in Section S2 and in Methods). The cell inlet, $C_{O 3, \text { cell_inlet, }}$ and outlet, $C_{O 3, \text { cell_inlet, }}$ concentrations are not measured directly but estimated as described 
here. The system outlet concentration, $C_{03, \text { system_outlet, }}$ is directly measured at the monitor and corrected for dilution. We define fractional removal values here to simplify later equations.

$f_{\text {system }}=\frac{C_{\text {O3,system_outlet }}}{C_{\text {O3,_system_inlet }}}$

$f_{\text {skin }}=\frac{C_{03, \text { cell_outlet }}}{C_{\text {O3,cell_inlet }}}$

Here, we define $f_{\text {skin }}$ to be the fraction associated only with ozone removal at the skin surface, which assumes that the PFA surfaces of the cell do not significantly remove ozone relative to skin or uptake to the tubing surfaces. Since tubing comprises approximately $90 \%$ of all surface area in the sampling system, this may be reasonable. For experiments in which the ozone removal for the system in the absence of skin (replaced by the flat back of a PFA flux cell), we define background fractional removal as follows

$f_{\text {system }, b}=\frac{C_{03, \text { system }_{\text {outlet }}{ }^{b}}}{C_{03, \text { system }_{\text {inlet }}{ }^{b}}}$

Assuming that removal is first order throughout the system and all tubing and cell surfaces are equally reactive with ozone (e.g. same ozone reaction probability aka "uptake coefficient"), then we can estimate fractional removal across the flux cell during an experiment:

$f_{\text {skin }}=\frac{f_{\text {system }}}{f_{\text {system }, b}}$

If the cell surfaces dominate ozone removal (if tubing is considered non-reactive), then $f_{\text {system, } b}$ is the result of ozone uptake on flux cell and blank surface. Since the area of the blank surface, $A_{\text {blank }}$, is $1.98 \mathrm{~cm}^{2}$ and the flux cell surface area, $A_{\text {flux_cell, }}$ is $6.73 \mathrm{~cm}^{2}$, we can estimate that the background removal associated with the flux cell surfaces alone is about $(6.73 /(1.98+6.73))$ or about $78 \%$ of the system background removal. More precisely,

$f_{\text {skin }}=\left[\frac{1}{f_{\text {system }}}+\left(\frac{A_{\text {flux_cell }}}{A_{\text {blank }}+A_{\text {flux_cell }}}\right)\left(1-\frac{1}{f_{\text {blank }}}\right)\right]^{-1}$

The deposition velocity associated with ozone uptake at skin can then be derived from $f_{\text {skin, }}$ (from either equation (S5) or (S6))

$v_{d, 03, \text { skin }}=\frac{Q}{A_{\text {skin }}}\left(\frac{1}{f_{\text {skin }}}-1\right)$

where, $Q$ is the volumetric flowrate. In these experiments, the difference between using equation (S5) or (S6) to determine the deposition velocity is about $25 \%$ (Average $10.1 \mathrm{~m} / \mathrm{h}$ and $12.5 \mathrm{~m} / \mathrm{h}$ respectively. Based on experience with minimal ozone loss in PFA tubing, we believe the second method better reflects the mechanisms of ozone loss in the system and we use this method to determine deposition velocity for all later calculations. 
S12 Results of factor analysis are shown here for 2-5 components.

Table S 4. Results of 2 component solution, along with representative example compounds

\begin{tabular}{|c|c|c|c|}
\hline \multirow[b]{2}{*}{ example } & \multirow[b]{2}{*}{ Ion } & \multicolumn{2}{|c|}{ Component } \\
\hline & & 1 & 2 \\
\hline C10-MUC & $\mathrm{C} 10 \mathrm{H} 15 \mathrm{O}+$ & 0.926 & \\
\hline C5-MUC & $\mathrm{C} 5 \mathrm{H} 7 \mathrm{O}+$ & 0.845 & 0.217 \\
\hline butyric acid & $\mathrm{C} 4 \mathrm{H} 9 \mathrm{O} 2+$ & 0.838 & 0.208 \\
\hline 4-oxopentenal & $\mathrm{C} 5 \mathrm{H} 7 \mathrm{O} 2+$ & 0.837 & 0.239 \\
\hline hexenoic acid & $\mathrm{C} 6 \mathrm{H} 11 \mathrm{O} 2+$ & 0.820 & -0.179 \\
\hline pentanoic acid & C5H11O2+ & 0.798 & 0.161 \\
\hline heptenal/heptenone & $\mathrm{C} 7 \mathrm{H} 13 \mathrm{O}+$ & 0.793 & 0.474 \\
\hline pentenal/pentenone & $\mathrm{C} 5 \mathrm{H} 9 \mathrm{O}+$ & 0.793 & \\
\hline C9-MUC & $\mathrm{C} 9 \mathrm{H} 15 \mathrm{O}+$ & 0.765 & \\
\hline 4-MOD & $\mathrm{C} 9 \mathrm{H} 15 \mathrm{O} 2+$ & 0.723 & -0.387 \\
\hline MVK/MACR & $\mathrm{C} 4 \mathrm{H} 7 \mathrm{O}+$ & 0.718 & 0.612 \\
\hline 4-MON & $\mathrm{C} 10 \mathrm{H} 17 \mathrm{O} 2+$ & 0.708 & 0.130 \\
\hline butanedial & $\mathrm{C} 4 \mathrm{H} 7 \mathrm{O} 2+$ & 0.677 & 0.160 \\
\hline heptenoic acid & $\mathrm{C} 7 \mathrm{H} 13 \mathrm{O} 2+$ & 0.674 & 0.307 \\
\hline acrylic acid & $\mathrm{C} 3 \mathrm{H} 5 \mathrm{O} 2+$ & 0.655 & \\
\hline 4-OPA & $\mathrm{C} 5 \mathrm{H} 9 \mathrm{O} 2+$ & 0.653 & -0.583 \\
\hline C9-MUC & $\mathrm{C} 9 \mathrm{H} 13 \mathrm{O}+$ & 0.605 & -0.316 \\
\hline unknown & C10H15O2+ & 0.603 & 0.216 \\
\hline C15-MUC & $\mathrm{C} 15 \mathrm{H} 23 \mathrm{O}+$ & -0.485 & -0.363 \\
\hline 4-oxo-butenoic acid & $\mathrm{C} 4 \mathrm{H} 5 \mathrm{O} 3+$ & 0.347 & \\
\hline nonenoic acid & $\mathrm{C} 9 \mathrm{H} 17 \mathrm{O} 2+$ & 0.132 & -0.871 \\
\hline $6 \mathrm{MHO}$ & $\mathrm{C} 8 \mathrm{H} 15 \mathrm{O}+$ & 0.181 & 0.829 \\
\hline unknown & $\mathrm{C} 8 \mathrm{H} 8 \mathrm{NO}+$ & 0.186 & -0.774 \\
\hline GA & $\mathrm{C} 13 \mathrm{H} 23 \mathrm{O}+$ & 0.313 & 0.772 \\
\hline octanal & $\mathrm{C} 8 \mathrm{H} 17 \mathrm{O}+$ & 0.189 & 0.771 \\
\hline $\mathrm{OH}-6 \mathrm{MHO}$ & $\mathrm{C} 8 \mathrm{H} 15 \mathrm{O} 2+$ & 0.468 & 0.738 \\
\hline decanediol & $\mathrm{C} 10 \mathrm{H} 23 \mathrm{O} 2+$ & 0.366 & 0.730 \\
\hline decanal & $\mathrm{C} 10 \mathrm{H} 21 \mathrm{O}+$ & 0.397 & 0.697 \\
\hline unknown & C8H11O2+ & 0.421 & -0.693 \\
\hline C7-MUC & C7H11O+ & 0.649 & 0.654 \\
\hline pentanal & $\mathrm{C} 5 \mathrm{H} 11 \mathrm{O}+$ & 0.195 & 0.652 \\
\hline C8-MUC & $\mathrm{C} 8 \mathrm{H} 13 \mathrm{O}+$ & 0.602 & 0.647 \\
\hline MEK/butanal & $\mathrm{C} 4 \mathrm{H} 9 \mathrm{O}+$ & 0.451 & 0.646 \\
\hline geraniol & C10H190+ & 0.486 & 0.627 \\
\hline unknown & $\mathrm{C} 7 \mathrm{H} 9 \mathrm{O} 3+$ & -0.193 & -0.624 \\
\hline heptanal & $\mathrm{C} 7 \mathrm{H} 15 \mathrm{O}+$ & 0.147 & 0.561 \\
\hline 4DMD & $\mathrm{C} 14 \mathrm{H} 21 \mathrm{O} 2+$ & -0.333 & -0.525 \\
\hline undecanal & $\mathrm{C} 11 \mathrm{H} 23 \mathrm{O}+$ & 0.455 & 0.487 \\
\hline hexanal & $\mathrm{C} 6 \mathrm{H} 13 \mathrm{O}+$ & -0.142 & 0.446 \\
\hline nonanal & $\mathrm{C} 9 \mathrm{H} 190+$ & & 0.347 \\
\hline nonanediol & $\mathrm{C} 9 \mathrm{H} 21 \mathrm{O} 2+$ & & 0.341 \\
\hline nonenal & $\mathrm{C} 9 \mathrm{H} 17 \mathrm{O}+$ & & 0.196 \\
\hline
\end{tabular}


Table S 5. Results of 3 component solution, along with representative example compounds

\begin{tabular}{|c|c|c|c|c|}
\hline \multirow[b]{2}{*}{ example } & \multirow[b]{2}{*}{ Ion } & \multicolumn{3}{|c|}{ Component } \\
\hline & & 1 & 2 & 3 \\
\hline $6 \mathrm{MHO}$ & $\mathrm{C} 8 \mathrm{H} 15 \mathrm{O}+$ & 0.958 & & \\
\hline GA & $\mathrm{C} 13 \mathrm{H} 23 \mathrm{O}+$ & 0.940 & & \\
\hline $\mathrm{OH}-6 \mathrm{MHO}$ & $\mathrm{C} 8 \mathrm{H} 15 \mathrm{O} 2+$ & 0.896 & 0.233 & \\
\hline C8-MUC & $\mathrm{C} 8 \mathrm{H} 13 \mathrm{O}+$ & 0.864 & 0.376 & \\
\hline decanediol & $\mathrm{C} 10 \mathrm{H} 23 \mathrm{O} 2+$ & 0.850 & 0.142 & \\
\hline decanal & $\mathrm{C} 10 \mathrm{H} 21 \mathrm{O}+$ & 0.836 & 0.176 & \\
\hline octanal & $\mathrm{C} 8 \mathrm{H} 17 \mathrm{O}+$ & 0.826 & & 0.125 \\
\hline MVK/MACR & $\mathrm{C} 4 \mathrm{H} 7 \mathrm{O}+$ & 0.810 & 0.520 & \\
\hline geraniol & $\mathrm{C} 10 \mathrm{H} 190+$ & 0.809 & 0.272 & \\
\hline C7-MUC & $\mathrm{C} 7 \mathrm{H} 110+$ & 0.803 & 0.456 & 0.133 \\
\hline MEK/butanal & $\mathrm{C} 4 \mathrm{H} 9 \mathrm{O}+$ & 0.714 & 0.280 & 0.198 \\
\hline heptenal/heptenone & $\mathrm{C} 7 \mathrm{H} 13 \mathrm{O}+$ & 0.661 & 0.644 & \\
\hline pentanal & $\mathrm{C} 5 \mathrm{H} 110+$ & 0.641 & & 0.234 \\
\hline nonenoic acid & $\mathrm{C} 9 \mathrm{H} 1702+$ & -0.633 & 0.274 & -0.574 \\
\hline undecanal & $\mathrm{C} 11 \mathrm{H} 23 \mathrm{O}+$ & 0.583 & 0.315 & 0.114 \\
\hline C10-MUC & $\mathrm{C} 10 \mathrm{H} 15 \mathrm{O}+$ & 0.214 & 0.901 & \\
\hline hexenoic acid & $\mathrm{C} 6 \mathrm{H} 11 \mathrm{O} 2+$ & & 0.868 & \\
\hline C5-MUC & $\mathrm{C} 5 \mathrm{H} 7 \mathrm{O}+$ & 0.278 & 0.828 & 0.320 \\
\hline 4-MOD & $\mathrm{C} 9 \mathrm{H} 15 \mathrm{O} 2+$ & -0.222 & 0.815 & \\
\hline butyric acid & $\mathrm{C} 4 \mathrm{H} 9 \mathrm{O} 2+$ & 0.385 & 0.770 & \\
\hline C9-MUC & $\mathrm{C} 9 \mathrm{H} 15 \mathrm{O}+$ & 0.171 & 0.762 & 0.158 \\
\hline pentanoic acid & $\mathrm{C} 5 \mathrm{H} 11 \mathrm{O} 2+$ & 0.321 & 0.748 & \\
\hline 4-oxopentenal & $\mathrm{C} 5 \mathrm{H} 7 \mathrm{O} 2+$ & 0.449 & 0.746 & \\
\hline 4-OPA & $\mathrm{C} 5 \mathrm{H} 9 \mathrm{O} 2+$ & -0.291 & 0.736 & -0.380 \\
\hline pentenal/pentenone & $\mathrm{C} 5 \mathrm{H} 9 \mathrm{O}+$ & 0.331 & 0.715 & -0.208 \\
\hline C9-MUC & $\mathrm{C} 9 \mathrm{H} 13 \mathrm{O}+$ & -0.243 & 0.709 & \\
\hline butanedial & $\mathrm{C} 4 \mathrm{H} 7 \mathrm{O} 2+$ & 0.169 & 0.685 & 0.333 \\
\hline 4-MON & $\mathrm{C} 10 \mathrm{H} 17 \mathrm{O} 2+$ & 0.251 & 0.676 & 0.119 \\
\hline acrylic acid & $\mathrm{C} 3 \mathrm{H} 5 \mathrm{O} 2+$ & 0.183 & 0.626 & \\
\hline heptenoic acid & $\mathrm{C} 7 \mathrm{H} 13 \mathrm{O} 2+$ & 0.409 & 0.600 & 0.173 \\
\hline unknown & $\mathrm{C} 8 \mathrm{H} 11 \mathrm{O} 2+$ & -0.408 & 0.518 & -0.496 \\
\hline unknown & $\mathrm{C} 10 \mathrm{H} 15 \mathrm{O} 2+$ & 0.406 & 0.508 & \\
\hline 4-oxo-butenoic acid & $\mathrm{C} 4 \mathrm{H} 5 \mathrm{O} 3+$ & 0.114 & 0.327 & \\
\hline hexanal & $\mathrm{C} 6 \mathrm{H} 13 \mathrm{O}+$ & & & 0.937 \\
\hline nonanal & $\mathrm{C} 9 \mathrm{H} 190+$ & & & 0.900 \\
\hline nonanediol & $\mathrm{C} 9 \mathrm{H} 21 \mathrm{O} 2+$ & & & 0.893 \\
\hline nonenal & $\mathrm{C} 9 \mathrm{H} 17 \mathrm{O}+$ & -0.194 & 0.111 & 0.807 \\
\hline C15-MUC & $\mathrm{C} 15 \mathrm{H} 23 \mathrm{O}+$ & -0.177 & -0.510 & -0.666 \\
\hline unknown & $\mathrm{C} 8 \mathrm{H} 8 \mathrm{NO}+$ & -0.471 & 0.277 & -0.658 \\
\hline heptanal & $\mathrm{C} 7 \mathrm{H} 15 \mathrm{O}+$ & 0.350 & 0.101 & 0.594 \\
\hline unknown & C7H9O3+ & -0.449 & -0.117 & -0.556 \\
\hline 4DMD & $\mathrm{C} 14 \mathrm{H} 21 \mathrm{O} 2+$ & -0.397 & -0.275 & -0.509 \\
\hline
\end{tabular}


Table S 6. Results of 4 component solution, along with representative example compounds

\begin{tabular}{|c|c|c|c|c|c|}
\hline \multirow[b]{2}{*}{ example } & \multirow[b]{2}{*}{ Ion } & \multicolumn{4}{|c|}{ Component } \\
\hline & & 1 & 2 & 3 & 4 \\
\hline $6 \mathrm{MHO}$ & $\mathrm{C} 8 \mathrm{H} 15 \mathrm{O}+$ & 0.955 & & -0.133 & \\
\hline GA & $\mathrm{C} 13 \mathrm{H} 23 \mathrm{O}+$ & 0.941 & & & \\
\hline $\mathrm{OH}-6 \mathrm{MHO}$ & C8H15O2+ & 0.932 & 0.221 & & \\
\hline C8-MUC & $\mathrm{C} 8 \mathrm{H} 13 \mathrm{O}+$ & 0.903 & 0.302 & 0.122 & \\
\hline MVK/MACR & $\mathrm{C} 4 \mathrm{H} 7 \mathrm{O}+$ & 0.853 & 0.340 & 0.297 & \\
\hline decanediol & $\mathrm{C} 10 \mathrm{H} 23 \mathrm{O} 2+$ & 0.848 & & 0.170 & \\
\hline decanal & $\mathrm{C} 10 \mathrm{H} 210+$ & 0.837 & & 0.189 & \\
\hline C7-MUC & $\mathrm{C} 7 \mathrm{H} 11 \mathrm{O}+$ & 0.832 & 0.207 & 0.348 & 0.124 \\
\hline geraniol & $\mathrm{C} 10 \mathrm{H} 190+$ & 0.818 & & 0.230 & \\
\hline octanal & $\mathrm{C} 8 \mathrm{H} 17 \mathrm{O}+$ & 0.812 & -0.187 & & \\
\hline MEK/butanal & $\mathrm{C} 4 \mathrm{H} 9 \mathrm{O}+$ & 0.743 & 0.150 & 0.146 & 0.208 \\
\hline heptenal/heptenone & $\mathrm{C} 7 \mathrm{H} 13 \mathrm{O}+$ & 0.719 & 0.464 & 0.353 & 0.141 \\
\hline pentanal & C5H11O+ & 0.670 & & -0.145 & 0.271 \\
\hline nonenoic acid & $\mathrm{C} 9 \mathrm{H} 17 \mathrm{O} 2+$ & -0.597 & 0.516 & & -0.461 \\
\hline undecanal & $\mathrm{C} 11 \mathrm{H} 23 \mathrm{O}+$ & 0.582 & & 0.408 & \\
\hline heptenoic acid & $\mathrm{C} 7 \mathrm{H} 13 \mathrm{O} 2+$ & 0.466 & 0.439 & 0.333 & 0.226 \\
\hline hexenoic acid & $\mathrm{C} 6 \mathrm{H} 11 \mathrm{O} 2+$ & & 0.863 & 0.305 & 0.206 \\
\hline 4-OPA & $\mathrm{C} 5 \mathrm{H} 9 \mathrm{O} 2+$ & -0.211 & 0.843 & 0.212 & -0.228 \\
\hline pentenal/pentenone & $\mathrm{C} 5 \mathrm{H} 9 \mathrm{O}+$ & 0.424 & 0.826 & 0.104 & \\
\hline unknown & C8H1102+ & -0.338 & 0.761 & & -0.336 \\
\hline pentanoic acid & C5H1102+ & 0.414 & 0.738 & 0.223 & 0.223 \\
\hline unknown & $\mathrm{C} 8 \mathrm{H} 8 \mathrm{NO}+$ & -0.413 & 0.678 & -0.248 & -0.487 \\
\hline butyric acid & $\mathrm{C} 4 \mathrm{H} 9 \mathrm{O} 2+$ & 0.468 & 0.677 & 0.325 & 0.187 \\
\hline C9-MUC & $\mathrm{C} 9 \mathrm{H} 15 \mathrm{O}+$ & 0.247 & 0.629 & 0.387 & 0.249 \\
\hline C9-MUC & $\mathrm{C} 9 \mathrm{H} 13 \mathrm{O}+$ & -0.243 & 0.177 & 0.911 & \\
\hline butanedial & $\mathrm{C} 4 \mathrm{H} 7 \mathrm{O} 2+$ & 0.183 & 0.157 & 0.816 & 0.265 \\
\hline 4-MON & $\mathrm{C} 10 \mathrm{H} 17 \mathrm{O} 2+$ & 0.257 & 0.165 & 0.811 & \\
\hline 4-oxo-butenoic acid & C4H5O3+ & & -0.243 & 0.797 & -0.198 \\
\hline 4-MOD & $\mathrm{C} 9 \mathrm{H} 15 \mathrm{O} 2+$ & -0.192 & 0.439 & 0.774 & \\
\hline C5-MUC & $\mathrm{C} 5 \mathrm{H} 7 \mathrm{O}+$ & 0.334 & 0.458 & 0.663 & 0.338 \\
\hline 4-oxopentenal & C5H7O2+ & 0.482 & 0.372 & 0.658 & \\
\hline C10-MUC & $\mathrm{C} 10 \mathrm{H} 15 \mathrm{O}+$ & 0.273 & 0.607 & 0.651 & \\
\hline acrylic acid & C3H5O2+ & 0.211 & 0.347 & 0.543 & \\
\hline unknown & $\mathrm{C} 10 \mathrm{H} 15 \mathrm{O} 2+$ & 0.420 & 0.216 & 0.491 & \\
\hline 4DMD & $\mathrm{C} 14 \mathrm{H} 21 \mathrm{O} 2+$ & -0.396 & 0.117 & -0.457 & -0.431 \\
\hline hexanal & $\mathrm{C} 6 \mathrm{H} 13 \mathrm{O}+$ & & -0.122 & & 0.953 \\
\hline nonanal & $\mathrm{C} 9 \mathrm{H} 19 \mathrm{O}+$ & & & & 0.919 \\
\hline nonanediol & $\mathrm{C} 9 \mathrm{H} 21 \mathrm{O} 2+$ & & & & 0.911 \\
\hline nonenal & $\mathrm{C} 9 \mathrm{H} 17 \mathrm{O}+$ & -0.138 & 0.148 & & 0.883 \\
\hline C15-MUC & $\mathrm{C} 15 \mathrm{H} 23 \mathrm{O}+$ & -0.236 & -0.292 & -0.333 & -0.706 \\
\hline heptanal & $\mathrm{C} 7 \mathrm{H} 15 \mathrm{O}+$ & 0.390 & & & 0.634 \\
\hline unknown & $\mathrm{C} 7 \mathrm{H} 9 \mathrm{O} 3+$ & -0.444 & 0.199 & -0.299 & -0.483 \\
\hline
\end{tabular}


Table S 7. Results of 5 component solution, along with representative example compounds

\begin{tabular}{|c|c|c|c|c|c|c|}
\hline \multirow[b]{2}{*}{ example } & \multirow[b]{2}{*}{ Ion } & \multicolumn{5}{|c|}{ Component } \\
\hline & & 1 & 2 & 3 & 4 & 5 \\
\hline $6 \mathrm{MHO}$ & $\mathrm{C} 8 \mathrm{H} 15 \mathrm{O}+$ & 0.954 & -0.111 & & & -0.156 \\
\hline OH-6MHO & C8H15O2+ & 0.928 & 0.214 & & & \\
\hline GA & $\mathrm{C} 13 \mathrm{H} 23 \mathrm{O}+$ & 0.924 & -0.105 & 0.258 & & -0.202 \\
\hline C8-MUC & $\mathrm{C} 8 \mathrm{H} 13 \mathrm{O}+$ & 0.888 & 0.255 & 0.287 & & \\
\hline decanediol & $\mathrm{C} 10 \mathrm{H} 23 \mathrm{O} 2+$ & 0.850 & & & & 0.194 \\
\hline decanal & $\mathrm{C} 10 \mathrm{H} 21 \mathrm{O}+$ & 0.840 & & & & 0.234 \\
\hline MVK/MACR & $\mathrm{C} 4 \mathrm{H} 7 \mathrm{O}+$ & 0.839 & 0.314 & 0.338 & & 0.132 \\
\hline octanal & $\mathrm{C} 8 \mathrm{H} 17 \mathrm{O}+$ & 0.825 & -0.118 & -0.121 & & 0.217 \\
\hline C7-MUC & $\mathrm{C} 7 \mathrm{H} 11 \mathrm{O}+$ & 0.822 & 0.203 & 0.296 & 0.106 & 0.237 \\
\hline geraniol & $\mathrm{C} 10 \mathrm{H} 190+$ & 0.820 & 0.122 & & & 0.254 \\
\hline MEK/butanal & $\mathrm{C} 4 \mathrm{H} 9 \mathrm{O}+$ & 0.743 & 0.170 & & 0.192 & 0.144 \\
\hline heptenal/heptenone & $\mathrm{C} 7 \mathrm{H} 13 \mathrm{O}+$ & 0.693 & 0.388 & 0.515 & 0.142 & \\
\hline pentanal & C5H11O+ & 0.661 & & 0.109 & 0.290 & -0.265 \\
\hline nonenoic acid & $\mathrm{C} 9 \mathrm{H} 17 \mathrm{O} 2+$ & -0.612 & 0.465 & 0.125 & -0.448 & -0.200 \\
\hline undecanal & $\mathrm{C} 11 \mathrm{H} 23 \mathrm{O}+$ & 0.575 & & 0.266 & & 0.328 \\
\hline heptenoic acid & $\mathrm{C} 7 \mathrm{H} 13 \mathrm{O} 2+$ & 0.446 & 0.384 & 0.430 & 0.222 & \\
\hline hexenoic acid & $\mathrm{C} 6 \mathrm{H} 11 \mathrm{O} 2+$ & & 0.905 & 0.179 & 0.172 & 0.294 \\
\hline pentenal/pentenone & $\mathrm{C} 5 \mathrm{H} 9 \mathrm{O}+$ & 0.417 & 0.839 & 0.146 & & \\
\hline pentanoic acid & C5H11O2+ & 0.415 & 0.796 & & 0.188 & 0.267 \\
\hline 4-OPA & C5H9O2+ & -0.238 & 0.762 & 0.423 & -0.222 & \\
\hline utyric acid & $\mathrm{C} 4 \mathrm{H} 9 \mathrm{O} 2+$ & 0.464 & 0.716 & 0.201 & 0.153 & 0.304 \\
\hline unknown & C8H11O2+ & -0.356 & 0.706 & 0.207 & -0.327 & -0.190 \\
\hline unknown & $\mathrm{C} 8 \mathrm{H} 8 \mathrm{NO}+$ & -0.418 & 0.669 & & -0.480 & -0.273 \\
\hline -MON & $\mathrm{C} 10 \mathrm{H} 17 \mathrm{O} 2+$ & 0.216 & & 0.888 & & 0.296 \\
\hline unknown & $\mathrm{C} 10 \mathrm{H} 15 \mathrm{O} 2+$ & 0.370 & & 0.878 & & -0.131 \\
\hline C10-MUC & C10H15O+ & 0.238 & 0.514 & 0.730 & & 0.240 \\
\hline 4-oxopentenal & $2+$ & 0.450 & 0.283 & 0.704 & & 0.271 \\
\hline C5-MUC & $\mathrm{C} 5 \mathrm{H}$ & 0.304 & 0.378 & 0.695 & 0.328 & 0.300 \\
\hline 4-MOD & $\mathrm{C} 9 \mathrm{H} 15 \mathrm{O} 2+$ & -0.220 & 0.376 & 0.675 & & 0.436 \\
\hline C9-MUC & $\mathrm{C} 9 \mathrm{H} 15 \mathrm{O}+$ & 0.218 & 0.537 & 0.573 & 0.253 & \\
\hline hexanal & $\mathrm{C} 6 \mathrm{H} 13 \mathrm{O}+$ & & & -0.121 & 0.950 & \\
\hline nonanal & $\mathrm{C} 9 \mathrm{H} 19 \mathrm{O}+$ & & & 0.122 & 0.933 & \\
\hline nonanediol & $\mathrm{C} 9 \mathrm{H} 21 \mathrm{O} 2+$ & & -0.105 & 0.156 & 0.928 & \\
\hline nonenal & $\mathrm{C} 9 \mathrm{H} 17 \mathrm{O}+$ & -0.130 & 0.171 & & 0.881 & \\
\hline C15-MUC & C15H23O+ & -0.244 & -0.359 & & -0.670 & -0.429 \\
\hline heptanal & $\mathrm{C} 7 \mathrm{H} 15 \mathrm{O}+$ & 0.390 & & & 0.638 & \\
\hline unknown & C7H9O3+ & -0.445 & 0.184 & -0.152 & -0.467 & -0.294 \\
\hline butanedial & $\mathrm{C} 4 \mathrm{H} 7 \mathrm{O} 2+$ & 0.184 & 0.232 & 0.327 & 0.207 & 0.833 \\
\hline acrylic acid & C3H5O2+ & 0.225 & 0.480 & & -0.122 & 0.736 \\
\hline 4-oxo-butenoic acid & C4H5O3+ & & -0.227 & 0.410 & -0.234 & 0.690 \\
\hline C9-MUC & $\mathrm{C9H} 13 \mathrm{O}+$ & -0.263 & 0.153 & 0.620 & & 0.666 \\
\hline 4DMD & $\mathrm{C} 14 \mathrm{H} 21 \mathrm{O} 2+$ & -0.405 & & & -0.391 & -0.559 \\
\hline
\end{tabular}




\section{S13 Dynamic emissions of a series of carbonyl species}

Shown in Figure S12 is the dynamic increase in the normalized signals of $\mathrm{C}_{7}$ through $\mathrm{C}_{12}$ carbonyls (for one regular participant). These signals have been background subtracted, then normalized by the signal just prior to turning off ozone. The signal of larger, lower volatility oxidized products are slower to rise, delayed by their increasing affinity for the skin lipid layer. In other words, their higher lipid-air partition coefficients delay their release.

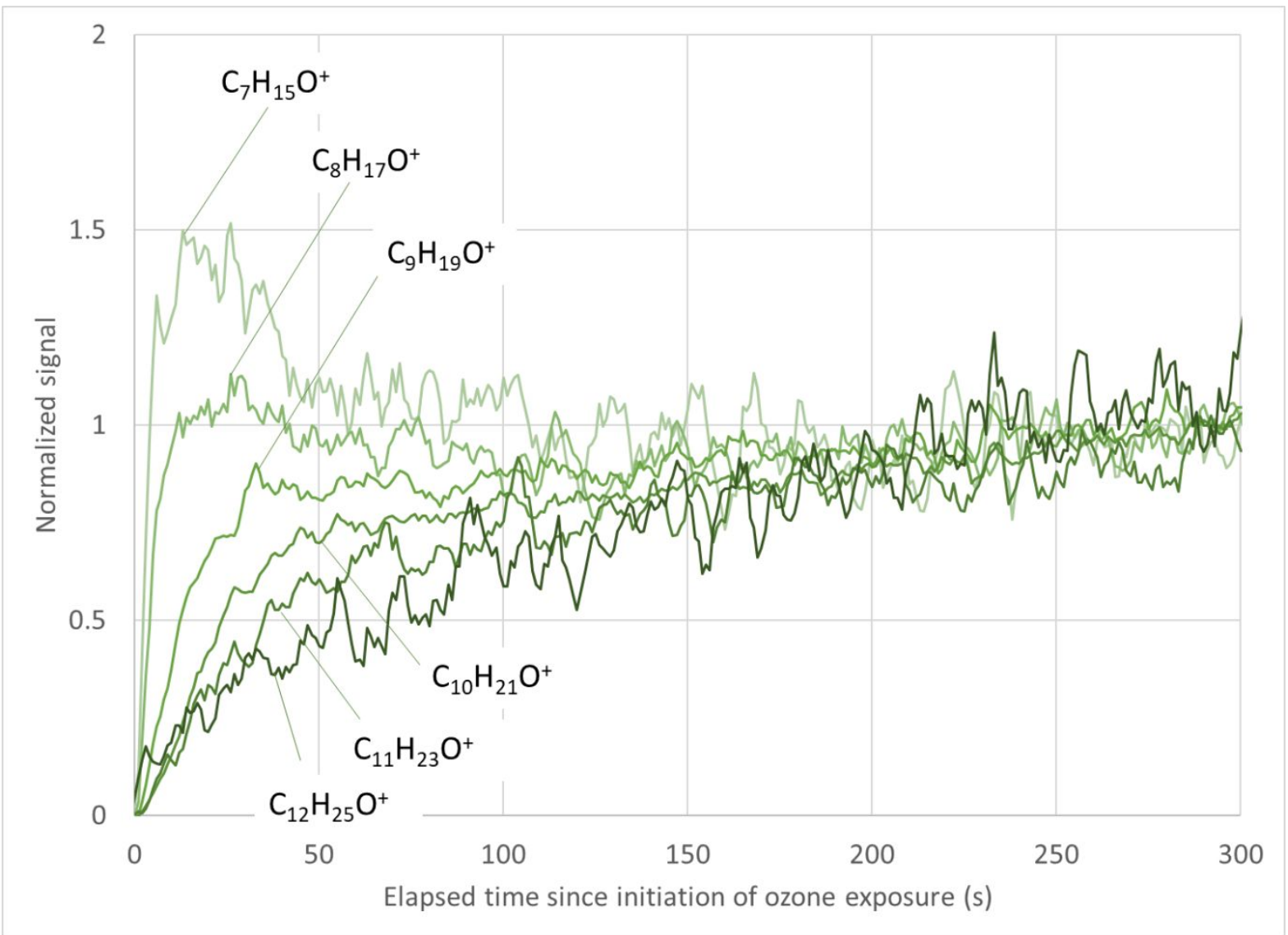

Figure S 12. Normalized dynamic signals of $C_{7}$ through $C_{12}$ aliphatic carbonyl compounds, example date from one subject.

\section{S14 Comparison with prior literature}

Skin lipid-specific yields estimated from full-scale exposure scenarios (e.g. human subjects in a room or chamber) are valuable because they represent in-situ results that can be related directly to model simulations ${ }^{7,8}$. However, due to sorption and reactions taking place in the room, as well as uncertainties in chemical kinetic or sorptive uptake parameters, the necessary back-calculations can introduce a relatively high degree of uncertainty. There have been only a few experiments that have measured the 
secondary emissions rates (or resulting air concentrations) of reaction products from skin lipids directly. For example, Pandrangi and Morrison ${ }^{9}$ exposed hair in a small reactor to ozone. They recorded inlet and outlet ozone mixing ratios as well as measured the concentrations of a handful of reaction products including nonanal, decanal, 6-MHO and GA. They reported total yields ranging from less than detection limits to greater than 1 for target species. Wisthaler and Weschler ${ }^{4}, 2010$ coated glass wool with skin lipids (forehead) and passed ozone through the wool directly into a proton-transfer reaction mass spectrometer (PTR-TOF-MS). They also exposed a small area of the forehead to ozone with somewhat different results. Similarly, Lakey et al. ${ }^{10}$ exposed a small area of skin to look at direct emissions for comparison with model. Wisthaler and Weschler ${ }^{4}$ and Lakey et al. ${ }^{10}$ did not report yields, but the relative proportion of compounds generated were indicative of squalene being a dominant source of oxidation products; it should be possible to retroactively estimate yields from the kinetic parameters that resulted from modelling of that system. Emissions rates and yields may also be generated from molecular dynamics simulations ${ }^{11}$.

Here we discuss some of the few articles that report surface-specific yields or from which we believe we can estimate yields based on information provided. Pandrangi and Morrison 9 reported yields of GA, 6$\mathrm{MHO}$, decanal and other species from exposing human hair to ozone; the hair was packed into a tube with air flowing through it directly into a sorptive sampler. The highest yields in that study, which due to the flow-path and sampling method are likely to be closer to the true surface yields were $0.29,0.56$ and 0.16 for GA, 6-MHO and decanal. All yields are higher than ours, but decanal was much higher. They also observed nonanal consistently with yields ranging from 0.01 to 0.18 . Wisthaler and Weschler ${ }^{4}$ exposing glass wool coated with skin oil to $100 \mathrm{ppb}_{3}$ packed in a tube (similar in design to Pandrangi and Morrison ) and measured the resulting products using a PTR-TOF-MS. They reported mixing ratios of GA, 6-MHO, decanal and 4-OPA of about 14, 13, 7 and $3 \mathrm{ppb}$. Since the amount of $\mathrm{O}_{3}$ that reacted was not reported, the minimum surface yield would be about $0.14,0.13,0.07$ and 0.03 if all $100 \mathrm{ppb}$ was consumed.

Two reported experiments are similar to ours in design but did not explicitly report yields. Wisthaler and Weschler ${ }^{4}$ exposed a small area of skin to ozone with a surface sampler. Upon exposing the skin to 50 $\mathrm{ppb}_{3}$, the resulting mixing ratios of $\mathrm{GA}, 6-\mathrm{MHO}$ and decanal were $0.15,2.5,0.7$ and $0.2 \mathrm{ppb}$ after 7 minutes of exposure. In a similar experiment, Lakey et al ${ }^{10}$ observed mixing ratios of GA, 6-MHO and 4OPA upon exposure to $72 \mathrm{ppb} \mathrm{O}_{3}$ of 3,11 and $1 \mathrm{ppb}$ respectively after 9 minutes of exposure. Again, $\mathrm{O}_{3}$ consumption was not reported for either experiment so measured surface yields cannot be determined 
directly, but assuming 50\% ozone consumed, yield estimates are shown in Table S8. For both cases, we observe that the yield of GA is much lower than for 6-MHO; authors suggested that GA desorbed slowly from skin lipids and had not achieved steady state under these conditions.

Surface yields have been calculated or can be estimated from chamber and field experiments. Salvador et al. ${ }^{7}$ performed chamber experiments with soiled t-shirts. They exposed these shirts to ozone in a roomsized chamber and measured the mixing ratios of volatile products using a PTR-TOF-MS. Using a chemical mass-balance model, they back-calculated surface yields of GA, 6-MHO and 4-OPA. For the three experiments that resulted in similar yields (one experiment deviated substantially), the average yields were $0.13,0.04$ and 0.07 respectively. Xiong et al. ${ }^{8}$ fit a chemical mass balance model to field data from a classroom and reported a formation rate constant of $0.025 \mathrm{~cm} / \mathrm{s}$ for $6-\mathrm{MHO}$. Combined with their estimated ozone deposition velocity to occupants $(0.25 \mathrm{~cm} / \mathrm{s})$, we estimate a surface yield for 6-MHO of 0.1 . 
Table S 8. Yields either directly reported by the authors or inferred from the information provided by the publication.

\begin{tabular}{|l|l|l|l|l|l|}
\hline & \multicolumn{3}{|l|}{ Product surface yield } & \\
\hline Study & GA & 6 -MHO & 4-OPA & decanal & Notes \\
\hline This study & 0.16 & 0.22 & 0.007 & 0.016 & Average from 20 participants \\
\hline $\begin{array}{l}\text { Pandrangi and } \\
\text { Morrison } \\
(2008)^{9}\end{array}$ & 0.29 & 0.56 & & 0.16 & $\begin{array}{l}\text { Maximum yields from hair in a plug-flow } \\
\text { reactor }\end{array}$ \\
\hline $\begin{array}{l}\text { Wisthaler and } \\
\text { Weschler } \\
(2010)^{4}\end{array}$ & 0.14 & 0.13 & 0.07 & 0.03 & $\begin{array}{l}\text { Minimum value based on full consumption } \\
\text { of O over coated glass wool in plug flow } \\
\text { reactor }\end{array}$ \\
\hline $\begin{array}{l}\text { Wisthaler and } \\
\text { Weschler } \\
(2010)^{4}\end{array}$ & 0.01 & 0.10 & 0.03 & 0.01 & $\begin{array}{l}\text { Based on in vivo measurements on skin, } \\
\text { reported mixing ratios, input ozone and an } \\
\text { assumption of 50\% O consumption }\end{array}$ \\
\hline $\begin{array}{l}\text { Lakey et al. } \\
(2017)^{10}\end{array}$ & 0.08 & 0.31 & 0.03 & $\begin{array}{l}\text { Based on in vivo measurements on skin, } \\
\text { reported mixing ratios, input ozone and an } \\
\text { assumption of 50\% O3 consumption. }\end{array}$ \\
\hline $\begin{array}{l}\text { Salvador et al } \\
(2019)^{7}\end{array}$ & 0.13 & 0.04 & & 0.07 & $\begin{array}{l}\text { Chemical mass balance back-calculation } \\
\text { based on results of ozone reactions with } \\
\text { skin-oil soiled t-shirts in flow-through } \\
\text { chamber. }\end{array}$ \\
\hline $\begin{array}{l}\text { Xiong et al. } \\
(2019)^{8}\end{array}$ & & 0.1 & & & $\begin{array}{l}\text { Estimated based on reported ozone } \\
\text { deposition velocity to occupants (0.25 } \\
\text { cm/s) and formation rate constant for 6- } \\
\text { MHO (0.025 cm/s). }\end{array}$ \\
\hline
\end{tabular}

\section{S15 References}

(1) Krechmer, J.; Lopez-Hilfiker, F.; Koss, A.; Hutterli, M.; Stoermer, C.; Deming, B.; Kimmel, J.; Warneke, C.; Holzinger, R.; Jayne, J.; Worsnop, D.; Fuhrer, K.; Gonin, M.; de Gouw, J. Evaluation of a New Reagent-Ion Source and Focusing Ion-Molecule Reactor for Use in Proton-Transfer-Reaction Mass Spectrometry. Anal. Chem. 2018, 90 (20), 12011-12018. https://doi.org/10.1021/acs.analchem.8b02641.

(2) Yuan, B.; Koss, A. R.; Warneke, C.; Coggon, M.; Sekimoto, K.; De Gouw, J. A. Proton-TransferReaction Mass Spectrometry: Applications in Atmospheric Sciences. Chemical Reviews 2017, 117 (21), 13187-13229. https://doi.org/10.1021/acs.chemrev.7b00325.

(3) Sekimoto, K.; Li, S.-M.; Yuan, B.; Koss, A.; Coggon, M.; Warneke, C.; de Gouw, J. Calculation of the Sensitivity of Proton-Transfer-Reaction Mass Spectrometry (PTR-MS) for Organic Trace Gases Using Molecular Properties. International Journal of Mass Spectrometry 2017, 421, 71-94.

(4) Wisthaler, A.; Weschler, C. J. Reactions of Ozone with Human Skin Lipids: Sources of Carbonyls, Dicarbonyls, and Hydroxycarbonyls in Indoor Air. Proceedings of the National Academy of Sciences of the United States of America 2010, 107 (15), 6568-6575.

(5) Pagonis, D.; Krechmer, J. E.; de Gouw, J.; Jimenez, J. L.; Ziemann, P. J. Effects of Gas-Wall Partitioning in Teflon Tubing and Instrumentation on Time-Resolved Measurements of Gas-Phase Organic Compounds. Atmospheric Measurement Techniques 2017, 10 (12). 
(6) Liu, X.; Deming, B.; Pagonis, D.; Day, D. A.; Palm, B. B.; Talukdar, R.; Roberts, J. M.; Veres, P. R.; Krechmer, J. E.; Thornton, J. A. Effects of Gas-Wall Interactions on Measurements of Semivolatile Compounds and Small Polar Molecules. Atmospheric Measurement Techniques 2019, 12 (6), 31373149.

(7) Salvador, C. M.; Bekö, G.; Weschler, C. J.; Morrison, G.; Le Breton, M.; Hallquist, M.; Ekberg, L.; Langer, S. Indoor Ozone/Human Chemistry and Ventilation Strategies. Indoor Air 2019, 29 (6), 913925. https://doi.org/10.1111/ina.12594.

(8) Xiong, J.; He, Z.; Tang, X.; Misztal, P. K.; Goldstein, A. H. Modeling the Time-Dependent Concentrations of Primary and Secondary Reaction Products of Ozone with Squalene in a University Classroom. Environmental Science and Technology 2019, 53 (14), 8262-8270. https://doi.org/10.1021/acs.est.9b02302.

(9) Pandrangi, L. S.; Morrison, G. C. Ozone Interactions with Human Hair: Ozone Uptake Rates and Product Formation. Atmospheric Environment 2008, 42 (20), 5079-5089.

(10) Lakey, P. S.; Wisthaler, A.; Berkemeier, T.; Mikoviny, T.; Pöschl, U.; Shiraiwa, M. Chemical Kinetics of Multiphase Reactions between Ozone and Human Skin Lipids: Implications for Indoor Air Quality and Health Effects. Indoor Air 2017, 27 (4), 816-828.

(11) Von Domaros, M.; Lakey, P. S.; Shiraiwa, M.; Tobias, D. J. Multiscale Modeling of Human Skin OilInduced Indoor Air Chemistry: Combining Kinetic Models and Molecular Dynamics. The Journal of Physical Chemistry B 2020, 124 (18), 3836-3843. 